\title{
VOLATILITY 'STRANGENESS' OF BONDS - HOW TO DEFINE AND WHAT DOES IT BRING?
}

\section{Bohumil Stádník, Václav Ždárek*}

\begin{abstract}
The aim of this article is to complement the existing economic and financial strand of the literature by defining three alternative regimes of the clean price volatility of a bond with respect to the level of interest rates in the economy. The suggested method takes into account responses to the changing nature of financial markets and allows for the possibility of observing negative interest rates. Our approach enables to find particular values of switching points between alternative regimes. After showing main theoretical steps, an investigation of the dependence of such points on key parameters of bonds is provided. An empirical illustration follows, accompanied by a discussion of theoretical and practical effects of this bond property. This approach offers both theorists and interested practitioners a way of overcoming difficulties associated with computations because of the complicated theoretical background. The results can be generalised, so that they apply both to the life of a bond and to the behaviour of a portfolio of bonds at a point of time.
\end{abstract}

Keywords: bond /portfolio of bonds, volatility regimes, price/yield sensitivity, negative interest rates

JEL Classification: G1, G10, G12, G14

\section{Introduction}

With the European sovereign debt crisis entering another phase characterised by very low inflation rates (or even mild deflation), several central banks have embarked upon the realisation of non-standard monetary policy measures (the so-called quantitative easing) or even setting negative interest rates directly. At the same time market interest rates have been very low or even negative challenging the theoretical notion of zero-lower bound allowing governments to issue bonds with negative yields. In this very environment, we study one common financial instrument - bond - both as an individual financial instrument and in a portfolio to shed more light on its behaviour and examine any deviations (abnormalities) in areas of very high positive and negative interest rates regarding price developments.

Investors' common concept of the clean bond price (in percentage of its face value) volatility behaviour is usually associated with a higher level of volatility, while its term to

Bohumil Stádník, Faculty of Finance and Accounting, University of Economics in Prague, Czech

Republic (bohumil.stadnik@vse.cz);

Václav Žd'árek, Škoda Auto Vysoká Škola, o.p.s, Mladá Boleslav, Czech Republic

(vaclav.zdarek@savs.cz).

The research has been supported by the Institutional Grant VŠE IP 100040 and by GA 16-21506S. 
maturity is also higher; in other words, a long-term bond tends to be more volatile than a shortterm one. This common concept has been introduced around mid-1980 by Fuller, Settle (1984). According to this common notion also the volatility of a typical bond is decreasing during its life as its term to maturity is also decreasing - presenting the "typical" volatility development according to this strand in the literature. However, it has been identified that with respect to the actual level of interest rates the behaviour of the bond volatility may change from "typical" volatility development to "non-typical". The latter is characterized with a particular volatility profile that is not always decreasing during a bond's life to maturity. As our model-based simulations reveal, in the case of extremely high levels of interest rates, even an "inverse" volatility development can be observed, especially when volatility is continuously increasing up to the beginning of the last coupon period. Conversely, if interest rates are low or very low (close to zero-lower-bound) this type of volatility can be seen only for bonds with long and very long maturities. This behaviour of bond volatility is both 'time dependent' (observable only for particular types of bonds) and 'evaluation method dependent' since it occurs when market participants utilize the discounted cash-flow model. To best of our knowledge, such behaviour has not been described in the literature yet.

In this text, we restrict our analysis to volatility patterns of a clean price of a typical fixed coupon rate bond without any embedded option (denoted as "bond" thereafter) with respect to the level of interest rates in the economy. ${ }^{1}$ This study belongs to a strand in the financial literature focussed on bonds behaviour such as Fabozzi (1993, 1995, 2010); Smit, Swart (2006); Málek, Radová, Štěrba (2007), bonds volatility (Litterman, Scheinkman, Weiss 1991), volatility of bonds' determinants (Fuller, Settle 1984), bond market price development over medium-run and long-run periods (Chance, Jordan 1966; Kang, Chen 2002; Tvaronavičienė, Michailova 2006; Křepelová, Jablonský 2013) or behaviour of a bond portfolio (Dzikevičius, Vetrov 2013).

Given the current low-inflation (land of-growth) and low-interest rate environment in many developed and developing countries around the world either very low or practically zero interest rate or even negative interest rates as outlined above, ${ }^{2}$ another section of this study is devoted to further examination of these effects on bond prices. Since bond price volatility has a great deal of practical importance for (institutional) portfolio managers, it

1 Because of space considerations (and many overlaps with our analysis), we do not consider any embedded option in our research and kindly recommend the reader interested in this topic the studies of Lim et al. (2012) or Horváth and Teplý (2013) for evaluating embedded options in construction of savings.

2 There are few examples within the European Union such as Denmark or Sweden whose central banks apply negative interest rates, the ECB, see for example Riksbank takes leap into the unknown with rate cut. Financial times, Friday, February 13, 2015, p. 6. or outside the EU it is Switzerland (since mid-December 2014 with a change in its policy) and Japan fighting deflation fears for years. Recently government bonds with negative yields for various maturities have been observed in many EU bond markets (Germany, Denmark, Austria, Sweden, Finland, Belgium, and the Netherlands) or even for longer maturities in Switzerland (up to 50 years as of early July 2016), for some early evidence see Webb (2015). Also the Czech government has been selling bonds with negative yields since summer 2015. Therefore, this opens a completely new area with consequences for their holding institutions (accounting principles, holding strategies, etc.). 
cannot be left out; one case is explored in the text. Our aim is to see what will happen when there is an expectation of possible higher changes in the interest rates. Not only that, but also related questions: what about lower interest rates? Does it hold as well?

There are many potential areas for application of our approach. One example being one certain bond life during which its term to maturity is decreasing and the price volatility is changing. One can ask a following question to be answered: How does the volatility development style depend on the time to maturity, coupon rate and on the level of interest rate (yield to maturity)? Because of similarities, another application is a straightforward extension, that being a portfolio of bonds with different maturities at a certain point of time.

Main contributions of this study lie in the careful examination of various regimes of bond volatility development with respect to the level of interest rates in the economy. Another is our suggestion as regards a method of finding particular switching values of interest rate between alternative regimes. We also investigate dependence of their localization (values) on parameters and show how to determine the minimum values and outline economic effects of this bonds' property for example for a practical portfolio management (see also Janda, Rausser, Svárovská 2014; Ortobelli, Tichý, 2015; Giacometti, Ortobelli, Tichý 2015; Blahová 2015; Brůna, Blahová 2016).

The structure of the remainder of the text is as follows: Section 2 reviews determinants of bond volatility and 'standard' volatility patterns. Section 3 describes regimes switching and its implications for volatility patterns. Section 4 offers a synthetic view through the lens of bond portfolio and shows examples from financial markets. Finally, Section 5 summarizes main findings and proposes future directions of research.

\section{A Brief Review of Volatility Determinants}

\subsection{Volatility and its determinants}

There are many authors describing volatility of bonds and its main determinants such the size of coupon, remaining time to maturity, the frequency of coupon payments, etc. ${ }^{3}$ Wilmott (2006) or Musílek (2011) provide a long list of determinants of bond prices and therefore, implicitly define factors affecting their volatility. Broadly defined, they can be classified as microeconomic (firm-specific factors), mezzo economic (industry- or (sub)sector-specific factors) and macroeconomic (main economic variables such as price indices or measures of production/consumption) and other determinants (investors' taste or preference shifters affecting for example the size of home bias, changes in institutional environment for some investors).

The clean price volatility of a bond is closely connected to the changes of yield to maturity or its expectation and also to the other market factors (Litterman, Scheinkman, 1991; Steeley, 2006; Meng, Gwilym, Varas, 2009) according to models describing general market price development. Changes of dirty price (i.e. bond price including accrued interest) with respect to the yield to maturity changes may be derived from the Equation (1), where

3 The readers wishing to refresh their knowledge can consult for example Wilmott (2006). 
we use simple interest inside the first coupon period and compounded yield in the rest of the periods (this style of calculation is also used by the US Treasury Convention, the socalled Moosmüller or Braß/Fangmayer yield, see Wilmott, 2006): ${ }^{4}$

$$
P(i)=\left(1+\frac{d}{T} i\right)^{-1}\left[c+\frac{c}{(1+i)}+\frac{c}{(1+i)^{2}}+\ldots+\frac{c+100}{(1+i)^{n-1}}\right],
$$

where $P$ is the dirty price of a bond in the percentage of its face value on purchasing day, $c$ is the coupon rate per the coupon period, $i$ is the yield to maturity per the coupon period, $d$ is the number of days between the first coupon payment and the purchasing day, $n$ is the number of coupon payments till the maturity and $T$ is the number of days inside the coupon period.

In the special case when we purchase a bond on the day with zero accrued interest (could be for example an ex-coupon day) and the clean price equals to the dirty price we can use the Formula (2) for the approximation of the required clean price development.

$$
P_{\text {clean }}(i)=\frac{c}{(1+i)}+\frac{c}{(1+i)^{2}}+\ldots+\frac{c+100}{(1+i)^{n}},
$$

where all variables have the same interpretation as in Equation (1).

Based on the Taylor's theorem for a real-valued function $f$ differentiable at the point $\alpha$, there is a polynomial approximation of a higher degree (quadratic, cubic, quartic...) at the fixed point $\alpha$. Taylor's theorem provides this approximation in a sufficiently small neighbourhood $(h)$ of the fixed point $\alpha$ :

$$
f(a+h)=f(a)+f^{\prime}(a) h+\frac{f^{\prime \prime}(a) h^{2}}{2 !}+\frac{f^{\prime \prime \prime}(a) h^{3}}{3 !}+\ldots+R,
$$

where Formula (3) is applied to Formula (2) and with the substitution: $h$ for $\Delta i$ and $f(a)$ for $P$. Consequently, it can be shown that, the Expression (4) holds:

$$
\Delta P_{\text {clean }}(i)=P_{\text {clean }}^{\prime}(i) \Delta i+\frac{P_{\text {clean }}^{\prime \prime}(i) \Delta i^{2}}{2 !}+\frac{P_{\text {clean }}^{\prime \prime \prime}(i) \Delta i^{3}}{3 !}+\ldots+R,
$$

where $R$ is the remainder of the series and $\Delta i$ is the change in the market interest rate. ${ }^{5}$

Using the Formula (4) for $\Delta P_{\text {clean }}$ (as percentage of its face value) as the general measure of volatility and only up to the second order approximation:

$$
\Delta P_{\text {clean }}(i) \cong-M a c_{\text {dur }} \frac{P_{\text {clean }}}{(1+i)} \Delta i+\frac{1}{2} P_{\text {clean }} \cdot \operatorname{Conv} \cdot \Delta i^{2},
$$

$4 \quad$ Each of the method is utilized by different financial institution and country. Both methods give the same results and at the day of coupon payment. In case of European markets, the ISMA standard is utilized (International Securities Market Association is a part of the International Capital Market Association).

5 For practical applications higher orders than [second/third] are omitted since the error due to the approximation is negligible, see Bartle and Sherbert (2011). 
where $M a c_{d u r}$ is the Macaulay's duration and the term Conv stands for the convexity of the bond, defined in Formula (6b) below. ${ }^{6}$ Both formulae utilized in Expression (5) can be specified using the following shorthand notation:

and convexity as

$$
M a c_{d u r}=\frac{\sum_{k=1}^{n} \frac{k \cdot c}{(1+i)^{k}}+\frac{n \cdot 100}{(1+i)^{n}}}{P_{\text {clean }}}
$$

$$
\text { Conv }=\frac{P_{\text {clean }}^{\prime \prime}(i)}{P_{\text {clean }}} .
$$

From the Formula (5) it is evident that the Macaulay's duration is not the only determinant of volatility which is often commonly accepted but $\Delta P$ depends also on the interest rate level. Figure 1 in two panels shows volatility profiles of 5-year and 10year futures contracts (the same effect is observable for bonds as they are their underlying assets) for two periods: months of 2012 (panel a) with a visible effects of 'whatever-ittakes message' and months of late 2014-early 2015 (panel b) capturing announcement and first effects of the extended asset purchases programme (QE) launched in early March by the ECB. It supports the mentioned commonly accepted idea where two times higher Macaulay's duration causes an approximately two times higher $\Delta P$. Such a situation is supported by Formula (5) if the price and the yield to maturity are of similar value. This feature is observable in today's low levels of interest rates. What may happen in case of increases/decreases of interest rate, will be discussed in the following text.

Figure 1 | Volatility Comparing of 5 and 10-years Futures Contracts (Euro-Bobl, Euro-Bund Futures), Daily Values

a) $2012 / \mathrm{M} 5-2012 / \mathrm{M} 11$
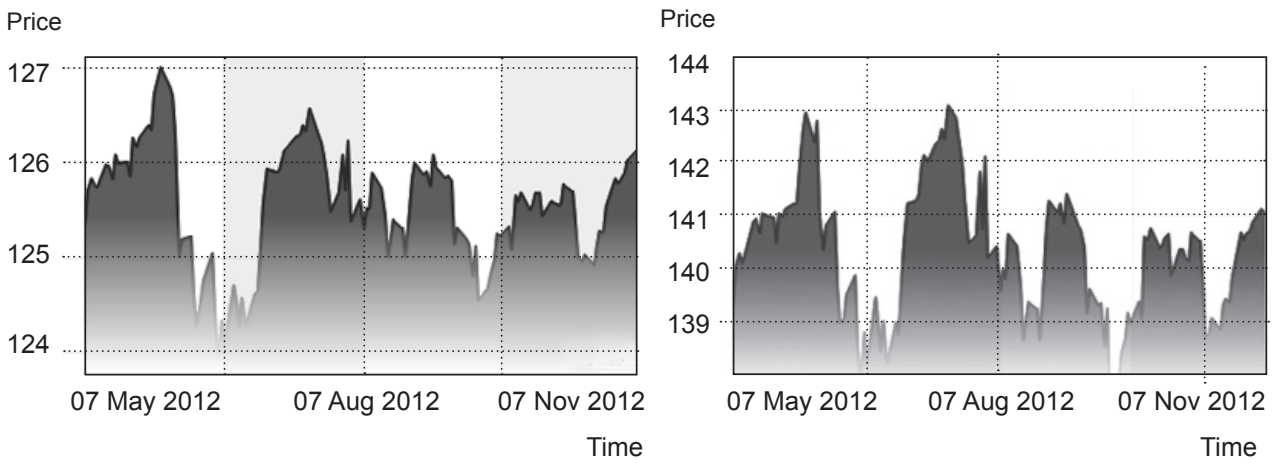

$6 \quad$ The convexity term in the Equation (5) for a price of a bond correct for a potential error in the approximation of price changes using the Taylor expansion (for discussion see for example Wilmott, 2006). One could use even higher order terms to 'improve' the precision of price change calculations, however, their size would be very small compared with complexity of their calculation and they are usually omitted. 
b) $2014 \mathrm{M} 11-2015 \mathrm{M} 3$
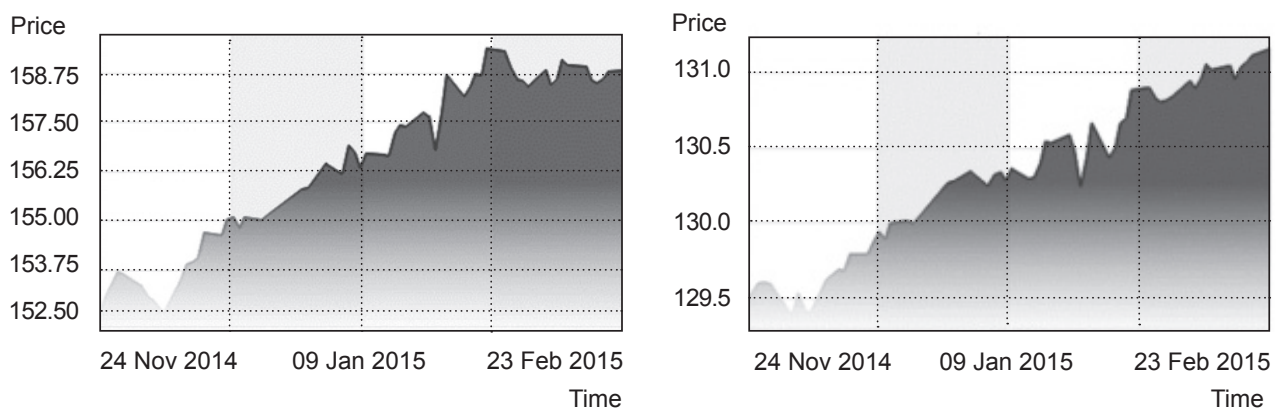

c) $2015 \mathrm{M} 1-2015 \mathrm{M} 4$
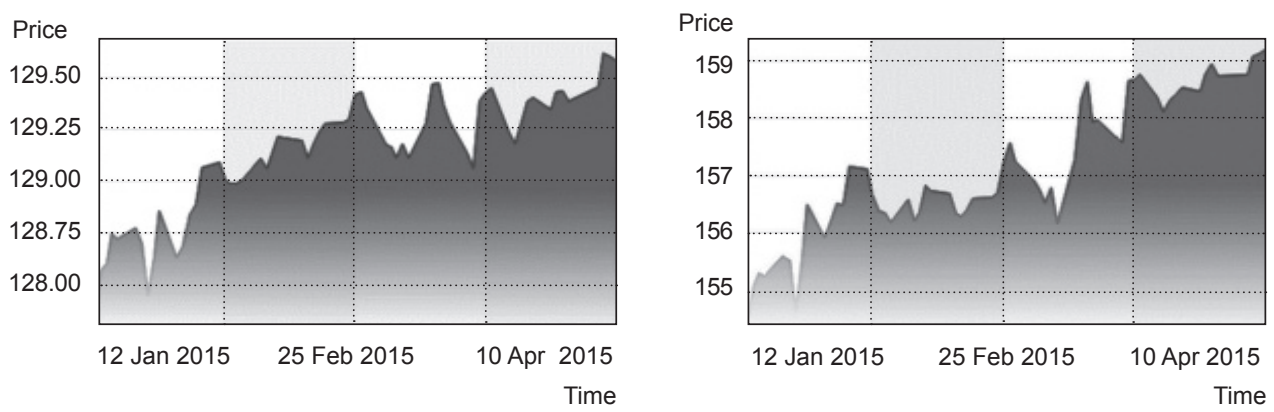

Source: EUREX (2015). www.eurexchange.com, 5 and 10-years futures contracts (Euro-Bobl, Euro-Bund Futures), daily data series.

\subsection{Bond volatility development during its life}

The clean price development with respect to discrete time $t$ (only for the days with zero accrued interest) can be expressed as shown in the Expression (7):

$$
P_{\text {clean }}(t)=c \cdot \frac{1-(1+i)^{-(n-t)}}{i}+\frac{100}{(1+i)^{(n-t)}} .
$$

The first and the second derivatives with respect to the discrete time (Equations (8) and (9)) describe the shape of the shape of the price development curve.

$$
\begin{aligned}
& P_{\text {clean }}^{\prime}(t)=\left(100-\frac{c}{i}\right) \cdot(1+i)^{t-n} \cdot \ln (1+i), \\
& P_{\text {clean }}^{\prime \prime}(t)=\left(100-\frac{c}{i}\right) \cdot(1+i)^{t-n} \cdot \ln ^{2}(1+i),
\end{aligned}
$$

where all the variables have the same interpretation as above. 
Panels of Figure 2 show an example, the clean and dirty price development of 30 and 8 years bond, fixed coupon rate $2.2 \%$ and $1.5 \%$ p.a., coupon frequency equals one year and we assume the constant yield to maturity $2 \%$ p.a. over the whole time till maturity (see Stádník, 2012, 2014). The clean price development is denoted in the figure as "constant yield to maturity curve" for yield to maturity equals $2 \%$ p.a. The time period in the picture is from the purchase day up to 30 and 8 years.

\section{Figure 2 | Clean (smooth line) and Dirty Price Development}

a) Example I

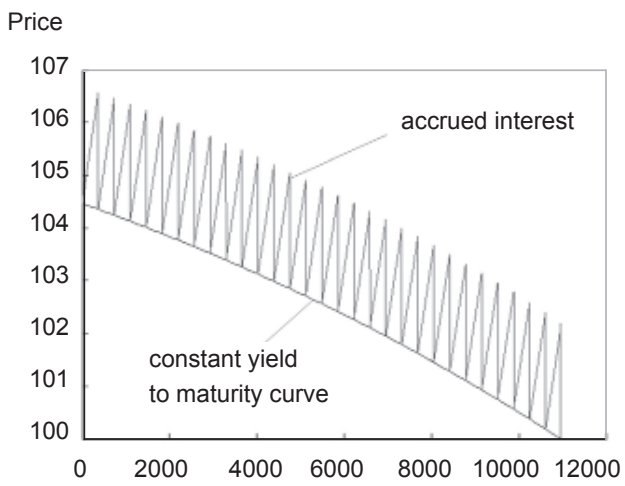

b) Example II

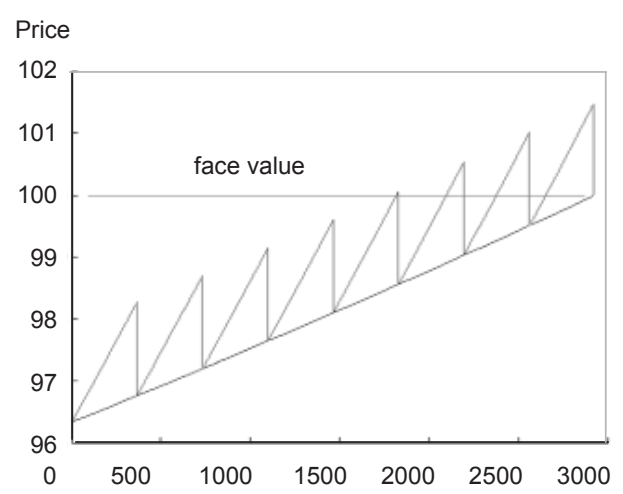

Note:

a) of 30 years bond, fixed coupon rate $2.2 \%$ p.a. yield to maturity;

b) of 8 years bond, fixed coupon rate $1.5 \%$ p.a. yield to maturity $2 \%$. Horizontal axis represent periods, vertical axis shows price levels.

Source: own illustration.

The 'Pull to Par' (price approaching to the par value at maturity) effect can be observed in Figure 2. ${ }^{7}$ However, the price development shown in the Figure 2 is only theoretical since the yield to maturity is changing at time and differs from the purchase yield. For example in Figures 4 to 6 the initial purchase clean price starts at certain point $P_{p}$ (Purchasing Price). If the yield to maturity is not changing till maturity the chart will be the smooth line starting from $P_{p}$ ("constant yield to maturity curve"). When the value of the yield to maturity is changing the clean price deflects from the "constant yield to maturity curve". We expect the volatility to be higher with the higher clean price/yield sensitivity and lower with the sensitivity decreasing.

If we consider an example (according to the Figure 3 of a bond with coupon rate of $5 \%$, maturity 90 years (in financial markets there are traded bonds with maturity over hundred

$7 \quad$ It captures the convergence of a bond price to its par value over the course of time. It reflects the difference between coupon (nominal yield of a bond) and market interest rate. 
years, in some cases even reaching as many as 1000 years ('exotic-bond firms'), see Table 3 , and expected yield to maturity is allowed to change between $2 \%$ and the value of switching point 1 (the point will be exactly defined later in the text) then the volatility development at the time is symbolically shown in the Figure 4.

Figure 3 | Clean Price with Respect to Yield to Maturity

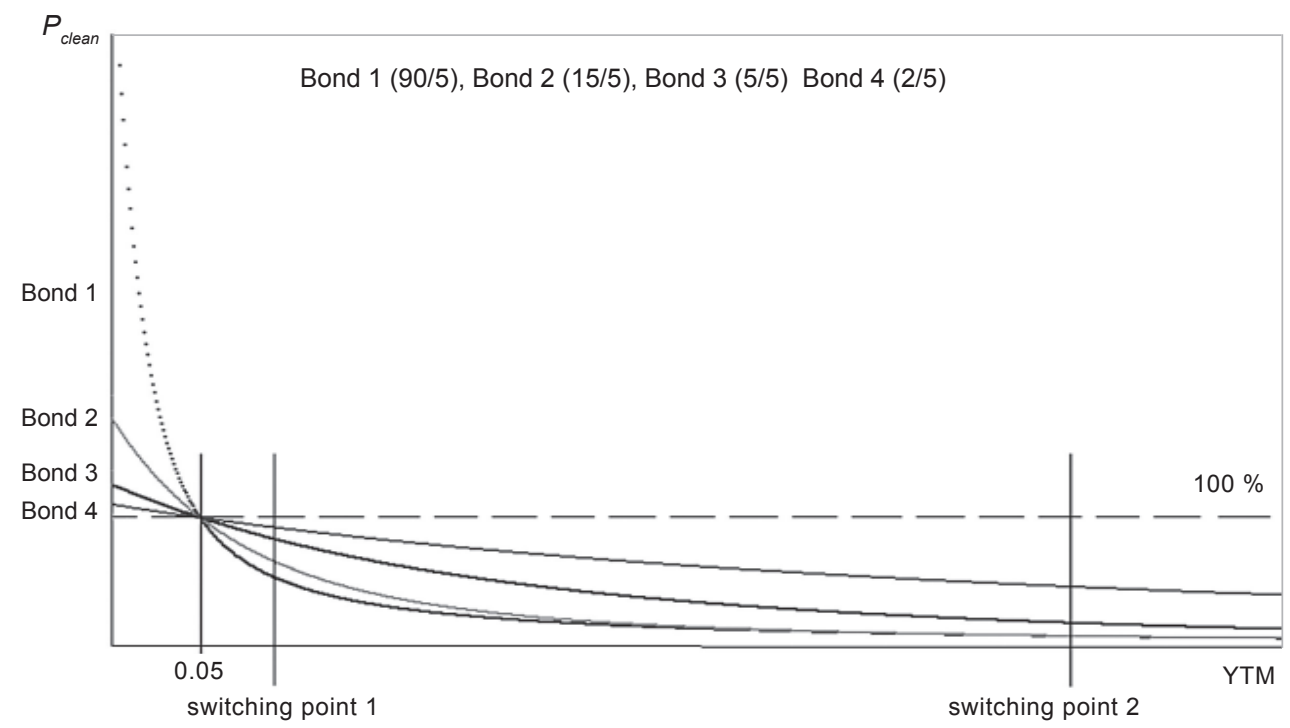

Note: $P_{\text {clean }}$ stands for the clean price, Bond 1 - a 90 -year bond, fixed coupon rate $5 \%$ p.a., Bond 2 - a 15 -year bond, fixed coupon rate $5 \%$ p.a., Bond3 - a 5 -year bond, fixed coupon rate $5 \%$ p.a. and Bond 4 - a 2-year bond, fixed coupon rate $5 \%$ p.a.

Source own illustration.

The feature of this development style can be derived from the Figure 3 in the following way. From the Figure 3 it is visually evident (without any mathematical approach) that if the yield to maturity is lower than switching point $1, \Delta P$ is increasing with respect to the higher term to maturity while $\Delta i$ remains the same. Our 90 years bond has 90 years to maturity on the purchase day and its clean price/yield characteristics is given by the curve for "Bond1" in the figure. After 75 years, when the bond has 15 years to maturity, its price/ yield characteristics is given by the curve for "Bond2" and while decreasing the time till maturity the characteristics is given analogically by the "Bond3" and "Bond4" curves. From the picture it is evident that the clean price/yield sensitivity is the highest for "Bond4" (the slope of the curve is the highest according to the Figure 3) then for "Bond3", "Bond2" and the lowest is for "Bond1". Such sensitivity changes during the bond life with its impact on volatility are shown in the Figure 4 - "typical" volatility development (see Stádník, 2014). In the figure we assume that yield to maturity varies between $2 \%$ and the value of switching point 1 . 


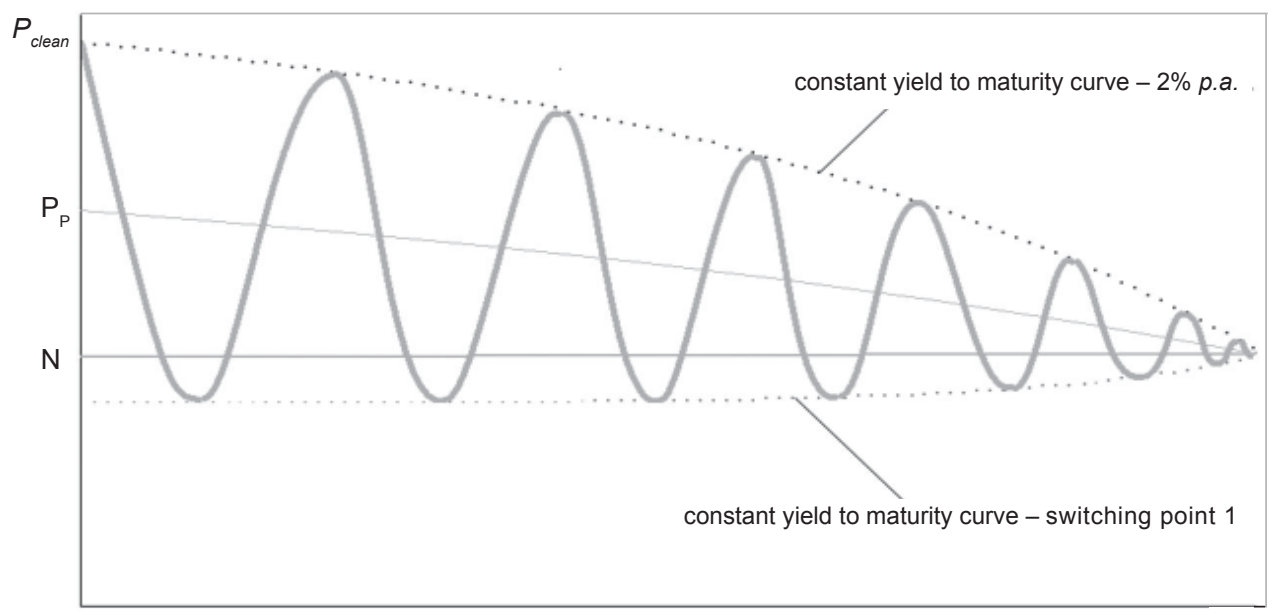

Time

Source: own illustration.

Considering the level of interest rates to be higher than those in the switching point 1 and lower than those in a certain switching point 2 during the bond life, then clean price/ yield sensitivity is evidently the highest for "Bond2" curve then for "Bond1", "Bond3", and the lowest is for "Bond4". Such situation is shown in the Figure 5 - "non-typical" volatility development. In the figure we assume that yield to maturity varies between the switching point 1 and the switching point 2 which creates "non-typical" volatility envelope.

\section{Figure 5 | Symbolic Image of Clean Price “Non-Typical” Volatility Envelope}

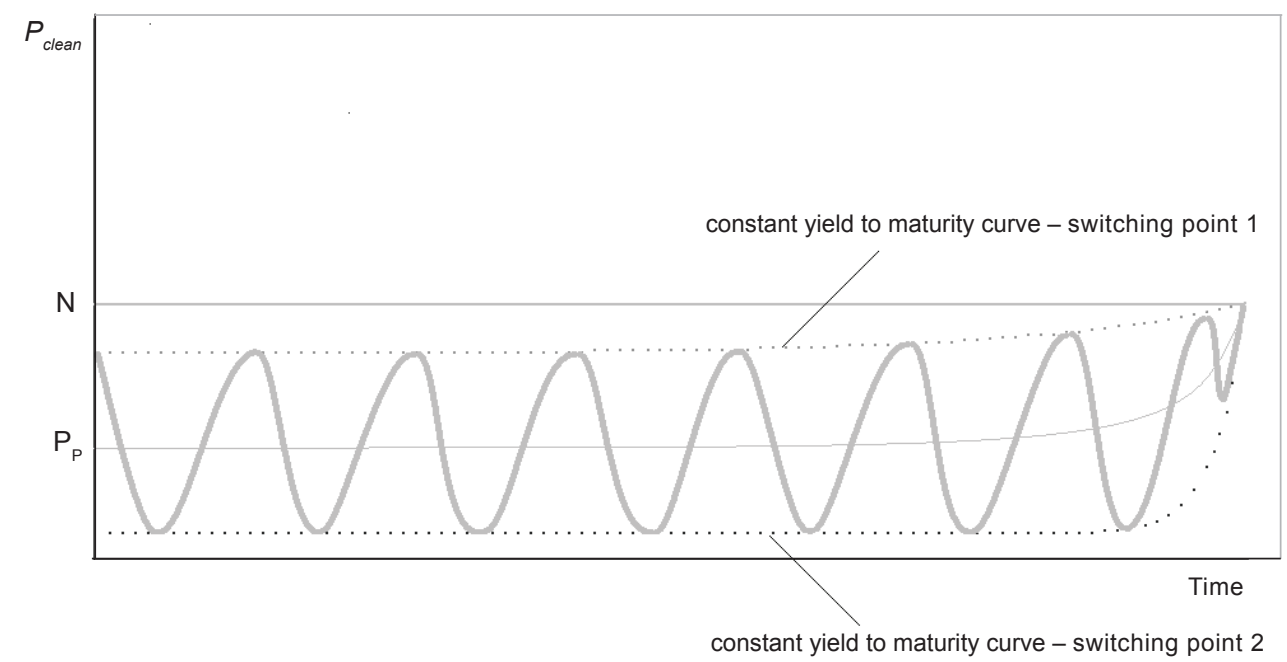

Source: own illustration. 
The volatility development is characterized by volatility increasing initially and consequently decreasing at the end of the life of the bond. In case of observing extremely high levels of interest rates (higher than the switching point 2) the price path can be shown as that in Figure 6 - "inverse" volatility development when the volatility continuously increases up to the beginning of the last coupon period. During the last coupon period the volatility decreases to zero at the maturity. In this example yield to maturity is assumed to vary between the switching point 2 and the maximum yield to maturity which creates an "inverse" volatility envelope.

\section{Figure 6 | Symbolic Image of Clean Price "Inverse" Volatility Envelope}

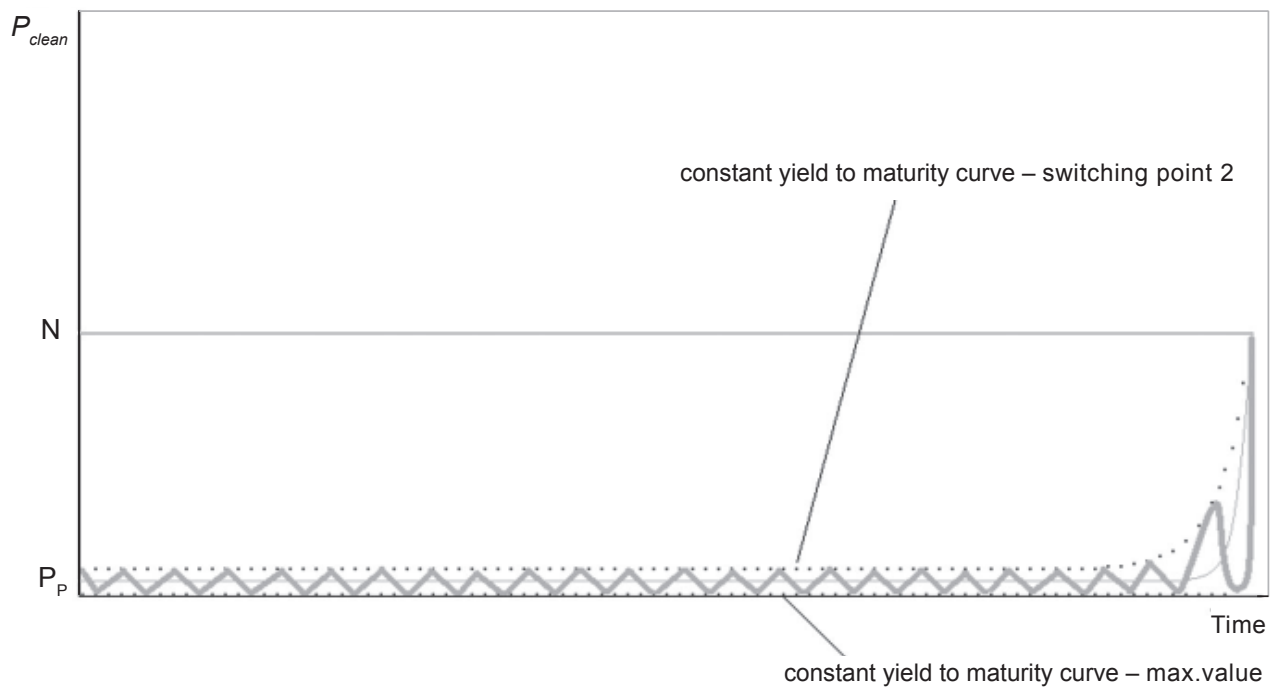

Source: own illustration.

Another special case could be the case presented in the Figure 7. This price development can occur when the level of interest rates changes across more volatility regimes, regardless of the direction of changes (increase/decrease) given the size of the change. In the case presented in the Figure 7, the purchase of a bond was during "typically" volatile period characterised by not frequently changing interest rates, followed by a return of interest rates behaviour to a "non-typically" volatile period, for example during a financial / banking / currency crisis.

All the previously described volatility patterns between the switching points 1 and 2 are shown for illustration together in the Figure 8. As explained above in the text, the parameters of switching point's curves depend on certain bond parameters. 


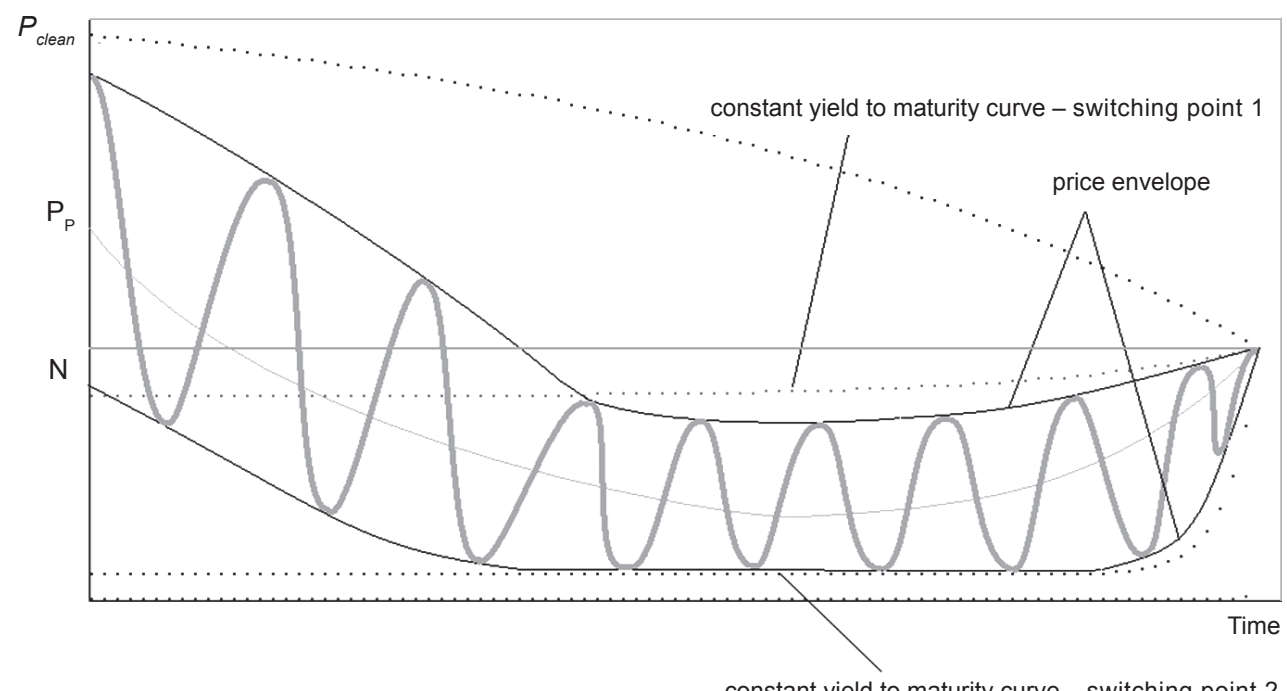

Source: own illustration.

Figure 8 | Symbolic Image of Clean Price Volatility Envelopes

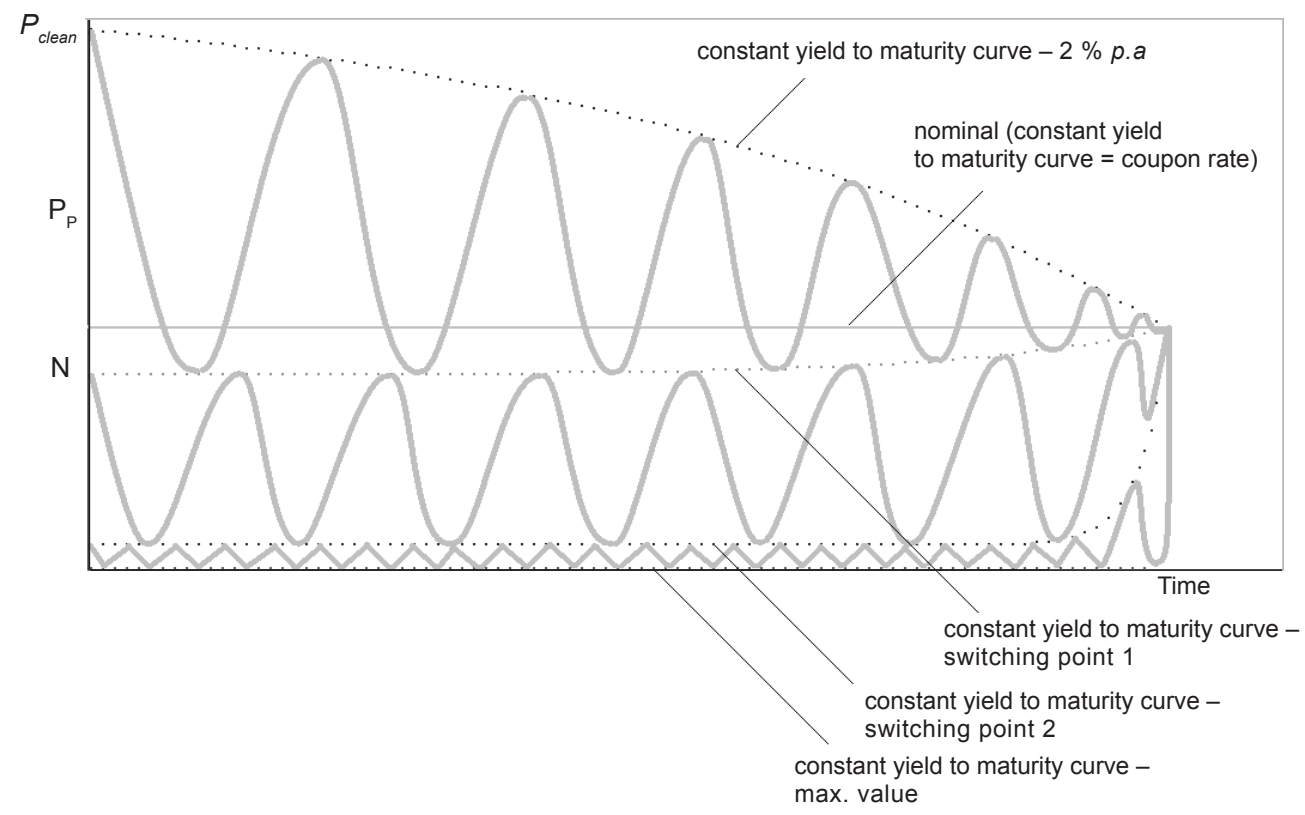

Source: own illustration. 


\section{How to Define Regime-Dependent Switching Points?}

For practical purposes we will show how to find the value of interest rate level where "typical" volatility path during a bond life changes to a "non-typical" one or even to an "inverse" one. Based on the Figure 3, we will assume that there is a minimum value of interest rate level where "typical" volatility development regime switches to "non-typical" regime and there is also another minimum point of interest rate when the regime is bound to give rise to its "inverse". Practical aspects are discussed in the Section 4.

Let's define the minimum interest rate level of switching between "typical" and "nontypical" volatility development as the switching point 1 and the minimum interest rate level of switching to "inverse" volatility development as the switching point 2 . In other words we can state that if the interest rate level arrives at some lower value switching point 1 , the sensitivity of a bond clean price starts to increase, while it has been decreasing until this moment. If the increase of interest rate level continues, then the switching point 2 can be reached and (price) sensitivity is increasing until the beginning of the last coupon period. We also expect that the switching point 1 is of lower value than the switching point 2 . We define the switching points as the lowest values on account of their possible practical impact with respect to the real level of the interest rates in an economy.

The switching point 1 is given as a solution on the lowest realisation of $i$ from one or more inequalities from the set of inequalities (10) where on the left and right sides of the inequalities are the first derivatives of the clean price with respect to $i$ and therefore, only the first term of the right side of the Equation (4) is utilized. For one certain period of bond life $c_{1}=c_{2}$ is set, $n$ is the number of coupon periods till maturity and $n=m+1$.

1. $-\frac{1 \cdot c_{1}}{(1+i)^{2}}-\frac{2 \cdot c_{1}}{(1+i)^{3}}-\ldots-\frac{m \cdot\left(c_{1}+100\right)}{(1+i)^{m+1}} \leq-\frac{1 \cdot c_{2}}{(1+i)^{2}}-\frac{2 \cdot c_{2}}{(1+i)^{3}}-\ldots-\frac{n \cdot\left(c_{2}+100\right)}{(1+i)^{n+1}}$

2. $-\frac{1 \cdot c_{1}}{(1+i)^{2}}-\frac{2 \cdot c_{1}}{(1+i)^{3}}-\ldots-\frac{(m-1)\left(c_{1}+100\right)}{(1+i)^{(m-1)+1}} \leq-\frac{1 \cdot c_{2}}{(1+i)^{2}}-\frac{2 \cdot c_{2}}{(1+i)^{3}}-\ldots-\frac{(n-1)\left(c_{2}+100\right)}{(1+i)^{(n-1)+1}}$

3. $-\frac{1 \cdot c_{1}}{(1+i)^{2}}-\frac{2 \cdot c_{1}}{(1+i)^{3}}-\ldots-\frac{(m-2)\left(c_{1}+100\right)}{(1+i)^{(m-2)+1}} \leq-\frac{1 \cdot c_{2}}{(1+i)^{2}}-\frac{2 \cdot c_{2}}{(1+i)^{3}}-\ldots-\frac{(n-2)\left(c_{2}+100\right)}{(1+i)^{(n-2)+1}}$

$(n-1)$.

$$
-\frac{\left(c_{1}+100\right)}{(1+i)^{2}} \leq-\frac{1 \cdot c_{2}}{(1+i)^{2}}-\frac{2 \cdot\left(c_{2}+100\right)}{(1+i)^{3}}
$$

The switching point 2 is given as the solution on the lowest realistic $i$ for all the inequalities from the set of inequalities (10) instead of the last inequality. Based on the set of the inequalities (10), various other characteristics can be also determined: (1) where the minimum value of interest rates can be found or (2) where a bond with a higher maturity starts to be more volatile than a bond with a lower maturity. 


\subsection{Results of numerical calculation of switching points}

Table 1a contains values of numerically solved switching points 1 for bond maturities ranging from 1 to 100 years and Table $1 \mathrm{~b}$ contains switching point solutions for a bond with extremely long time to maturity, between 100 and 1200 years. We consider the yield to maturity to be changing from $0 \%$ to $100 \%$ p.a. and coupon rates from $0 \%$ to $9 \%$ p.a. ${ }^{8}$

Table 1a | Switching Point 1 for a Long Maturity Bond (one bond life)

\begin{tabular}{|c|c|c|c|c|c|c|c|c|c|c|}
\hline \multirow{2}{*}{$\begin{array}{l}\text { matu- } \\
\text { rity }\end{array}$} & \multicolumn{10}{|c|}{ coupon } \\
\hline & 0 & 1 & 2 & 3 & 4 & 5 & 6 & 7 & 8 & 9 \\
\hline 1 & $\mathrm{n}$ & $\mathrm{n}$ & $\mathrm{n}$ & $\mathrm{n}$ & $\mathrm{n}$ & $\mathrm{n}$ & $\mathrm{n}$ & $\mathrm{n}$ & $\mathrm{n}$ & $\mathrm{n}$ \\
\hline 2 & $\mathrm{n}$ & $\mathrm{n}$ & $\mathrm{n}$ & $\mathrm{n}$ & $\mathrm{n}$ & $\mathrm{n}$ & $\mathrm{n}$ & $\mathrm{n}$ & $\mathrm{n}$ & $\mathrm{n}$ \\
\hline 3 & 0.500 & 0.515 & 0.530 & 0.545 & 0.560 & 0.575 & 0.590 & $\mathrm{n}$ & $\mathrm{n}$ & $\mathrm{n}$ \\
\hline 4 & 0.333 & 0.347 & 0.360 & 0.373 & 0.387 & 0.400 & 0.413 & 0.427 & 0.440 & 0.453 \\
\hline 5 & 0.250 & 0.263 & 0.275 & 0.288 & 0.300 & 0.313 & 0.325 & 0.338 & 0.350 & 0.363 \\
\hline 6 & 0.200 & 0.212 & 0.224 & 0.236 & 0.248 & 0.260 & 0.272 & 0.284 & 0.296 & 0.308 \\
\hline 7 & 0.167 & 0.178 & 0.190 & 0.202 & 0.213 & 0.225 & 0.237 & 0.248 & 0.260 & 0.272 \\
\hline 8 & 0.143 & 0.154 & 0.166 & 0.177 & 0.189 & 0.200 & 0.211 & 0.223 & 0.234 & 0.246 \\
\hline 9 & 0.125 & 0.136 & 0.148 & 0.159 & 0.170 & 0.181 & 0.193 & 0.204 & 0.215 & 0.226 \\
\hline 10 & 0.111 & 0.122 & 0.133 & 0.144 & 0.156 & 0.167 & 0.178 & 0.189 & 0.200 & 0.211 \\
\hline 15 & 0.071 & 0.082 & 0.093 & 0.104 & 0.114 & 0.125 & 0.136 & 0.146 & 0.157 & 0.168 \\
\hline 20 & 0.053 & 0.063 & 0.074 & 0.084 & 0.095 & 0.105 & 0.116 & 0.126 & 0.137 & 0.147 \\
\hline 25 & 0.042 & 0.052 & 0.063 & 0.073 & 0.083 & 0.094 & 0.104 & 0.115 & 0.125 & 0.135 \\
\hline 30 & 0.034 & 0.045 & 0.055 & 0.066 & 0.076 & 0.086 & 0.097 & 0.107 & 0.117 & 0.128 \\
\hline 35 & 0.029 & 0.040 & 0.050 & 0.060 & 0.071 & 0.081 & 0.091 & 0.101 & 0.112 & 0.122 \\
\hline 40 & 0.026 & 0.036 & 0.046 & 0.056 & 0.067 & 0.077 & 0.087 & 0.097 & 0.108 & 0.118 \\
\hline 45 & 0.023 & 0.033 & 0.043 & 0.053 & 0.064 & 0.074 & 0.084 & 0.094 & 0.105 & 0.115 \\
\hline 50 & 0.020 & 0.031 & 0.041 & 0.051 & 0.061 & 0.071 & 0.082 & 0.092 & 0.102 & 0.112 \\
\hline 55 & 0.019 & 0.029 & 0.039 & 0.049 & 0.059 & 0.069 & 0.080 & 0.090 & 0.100 & 0.110 \\
\hline 60 & 0.017 & 0.027 & 0.037 & 0.047 & 0.058 & 0.068 & 0.078 & 0.088 & 0.098 & 0.108 \\
\hline 65 & 0.016 & 0.026 & 0.036 & 0.046 & 0.056 & 0.066 & 0.077 & 0.087 & 0.097 & 0.107 \\
\hline 70 & 0.014 & 0.025 & 0.035 & 0.045 & 0.055 & 0.065 & 0.075 & 0.086 & 0.096 & 0.106 \\
\hline 75 & 0.014 & 0.024 & 0.034 & 0.044 & 0.054 & 0.064 & 0.074 & 0.084 & 0.095 & 0.105 \\
\hline 80 & 0.013 & 0.023 & 0.033 & 0.043 & 0.053 & 0.063 & 0.073 & 0.084 & 0.094 & 0.104 \\
\hline 85 & 0.012 & 0.022 & 0.032 & 0.042 & 0.052 & 0.063 & 0.073 & 0.083 & 0.093 & 0.103 \\
\hline 90 & 0.011 & 0.021 & 0.031 & 0.042 & 0.052 & 0.062 & 0.072 & 0.082 & 0.092 & 0.102 \\
\hline 95 & 0.011 & 0.021 & 0.031 & 0.041 & 0.051 & 0.061 & 0.071 & 0.081 & 0.091 & 0.102 \\
\hline 100 & 0.010 & 0.020 & 0.030 & 0.040 & 0.051 & 0.061 & 0.071 & 0.081 & 0.091 & 0.101 \\
\hline
\end{tabular}

Note: $\mathrm{n}$ - switching points not defined.

Source: own calculation.

8 Some empirical evidence regarding financial instruments traded in financial markets with very long maturities and high coupons can be found in Tables 3 and 4 below. 
Considering firstly the frequency of coupon payments, let's assume them to be set to one year. In case of higher frequencies, results will be negligibly different, based on numerical calculation check. Using the Equation (7), accrued interest can be eliminated as this equation describes dirty price at the points of zero accrued interest. Therefore, the deterministic part of the development of clean price can be approximated which is what we are after in this text. As it can be easily verified, for higher maturities the switching point 1 is of lower value than in case of lower maturities which is in line with the notion sketched in Fuller, Settle (1984).

Table 1b | Switching Point 1 for Extremely Long Time to Maturity (one bond life)

\begin{tabular}{|l|c|c|c|c|c|c|c|c|c|c|}
\hline \multirow{2}{*}{$\begin{array}{l}\text { matu- } \\
\text { rity }\end{array}$} & $\mathbf{0}$ & $\mathbf{1}$ & $\mathbf{2}$ & $\mathbf{3}$ & $\mathbf{4}$ & $\mathbf{5}$ & $\mathbf{6}$ & $\mathbf{7}$ & $\mathbf{8}$ & $\mathbf{9}$ \\
\hline $\mathbf{2 0 0}$ & 0.005 & 0.015 & 0.025 & 0.035 & 0.045 & 0.055 & 0.065 & 0.075 & 0.085 & 0.095 \\
\hline $\mathbf{3 0 0}$ & 0.003 & 0.013 & 0.023 & 0.033 & 0.044 & 0.054 & 0.064 & 0.074 & 0.084 & 0.094 \\
\hline $\mathbf{4 0 0}$ & 0.003 & 0.013 & 0.023 & 0.033 & 0.043 & 0.053 & 0.063 & 0.073 & 0.08 & 0.083 \\
\hline $\mathbf{5 0 0}$ & 0.002 & 0.012 & 0.022 & 0.032 & 0.042 & 0.052 & 0.062 & 0.066 & 0.067 & 0.068 \\
\hline $\mathbf{6 0 0}$ & 0.002 & 0.012 & 0.022 & 0.032 & 0.042 & 0.051 & 0.054 & 0.056 & 0.056 & 0.056 \\
\hline $\mathbf{7 0 0}$ & 0.001 & 0.012 & 0.022 & 0.032 & 0.041 & 0.046 & 0.048 & 0.047 & 0.049 & 0.049 \\
\hline $\mathbf{8 0 0}$ & 0.001 & 0.011 & 0.021 & 0.031 & 0.039 & 0.042 & 0.041 & 0.042 & 0.042 & 0.042 \\
\hline $\mathbf{9 0 0}$ & 0.001 & 0.011 & 0.021 & 0.031 & 0.036 & 0.037 & 0.037 & 0.037 & 0.038 & 0.038 \\
\hline $\mathbf{1 0 0 0}$ & 0.001 & 0.011 & 0.021 & 0.030 & 0.033 & 0.033 & 0.033 & 0.034 & 0.034 & 0.033 \\
\hline $\mathbf{1 1 0 0}$ & $\sim 0.001$ & 0.011 & 0.021 & 0.028 & 0.029 & 0.030 & 0.031 & 0.031 & 0.031 & 0.030 \\
\hline $\mathbf{1 2 0 0}$ & 0.001 & 0.011 & 0.021 & 0.027 & 0.027 & 0.029 & 0.029 & 0.029 & 0.029 & 0.029 \\
\hline
\end{tabular}

Note: increasing maturity to infinity leads to changes shown in Figure 9.

Source: own calculation.

The determination of the switching point 2 is shown in Table $1 \mathrm{c}$ as it is given as the solution on the lowest realization of $i$ for all the inequalities from the set of inequalities (10) but the last inequality. The switching point 2 is always higher than $50 \%$ for coupon rates higher than $1 \%$ and this value is given by switching point 1 between the lowest maturities for each coupon rate. ${ }^{9}$

9 Matlab version 2013b was utilized for a numerical calculation and the source code is in the Appendix. 
Table 1c | Switching Points $\mathbf{2}$ for Various Maturities (one bond life)

\begin{tabular}{|l|c|c|c|c|c|}
\hline \multirow{2}{*}{ maturity } & \multicolumn{5}{|c|}{ coupon } \\
\cline { 2 - 6 } & $\mathbf{c = 1}$ & $\mathbf{c = 3}$ & $\mathbf{c = 5}$ & $\mathbf{c = 7}$ & $\mathbf{c = 9}$ \\
\hline $\mathbf{1}$ & $\mathrm{n}$ & $\mathrm{n}$ & $\mathrm{n}$ & $\mathrm{n}$ & $\mathrm{n}$ \\
\hline $\mathbf{2}$ & $\mathrm{n}$ & $\mathrm{n}$ & $\mathrm{n}$ & $\mathrm{n}$ & $\mathrm{n}$ \\
\hline $\mathbf{3 - 1 0 0}$ & 0.516 & 0.545 & 0.575 & 0.605 & 0.635 \\
\hline
\end{tabular}

Note: $\mathrm{n}$ - switching points not defined.

Source: own calculation.

Volatility development of perpetuity can be derived from formula for the Macaulay's duration formula for perpetuity:

$$
M a c_{d u r}=c \cdot \frac{1+i}{i}
$$

Based on the Formula (11), it is obvious that a bond's sensitivity basically depends only on its yield to maturity and for a constant yield to maturity the volatility envelope has a constant shape according to the Figure 9.

Figure 9 | Symbolic Image of Clean Price Volatility Envelope of a Perpetuity

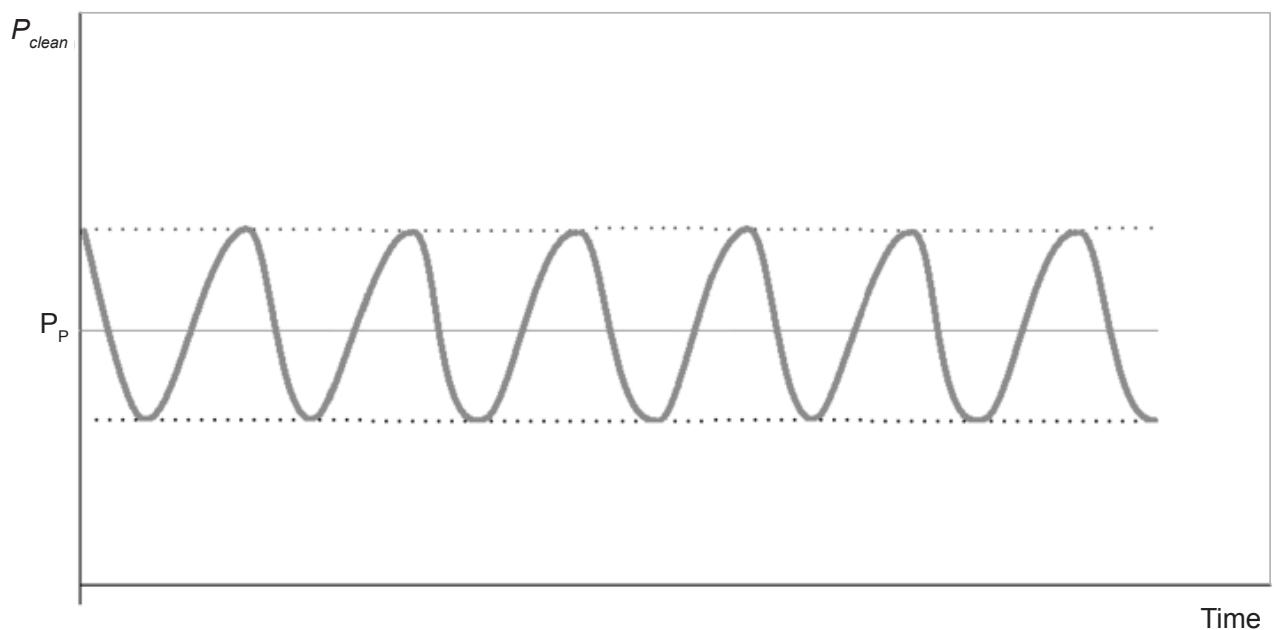

Note: band is defined as an area of possible price fluctuation between two yields to maturity of constant value

Source: own illustration. 


\subsection{Zero and negative interest rates}

Since institutional and individual investors can come across negative interest rates or even bonds with negative yields (outlined above), this section explicitly examines behaviour under these circumstances. To begin with, in case of constant yield to maturity which equals 0 (zero), the clean price development is not of a convex or of a concave shape as in all the other cases but the path is linear. Figure 10 illustrates a linear clean price development for constant yield to maturity $=0$ from purchase day till maturity of three bonds with maturity 50 years and coupon rates $1 \%, 2 \%$ and $3 \%$ p.a.

\section{Figure 10 | Clean Price Development of Three Bonds}

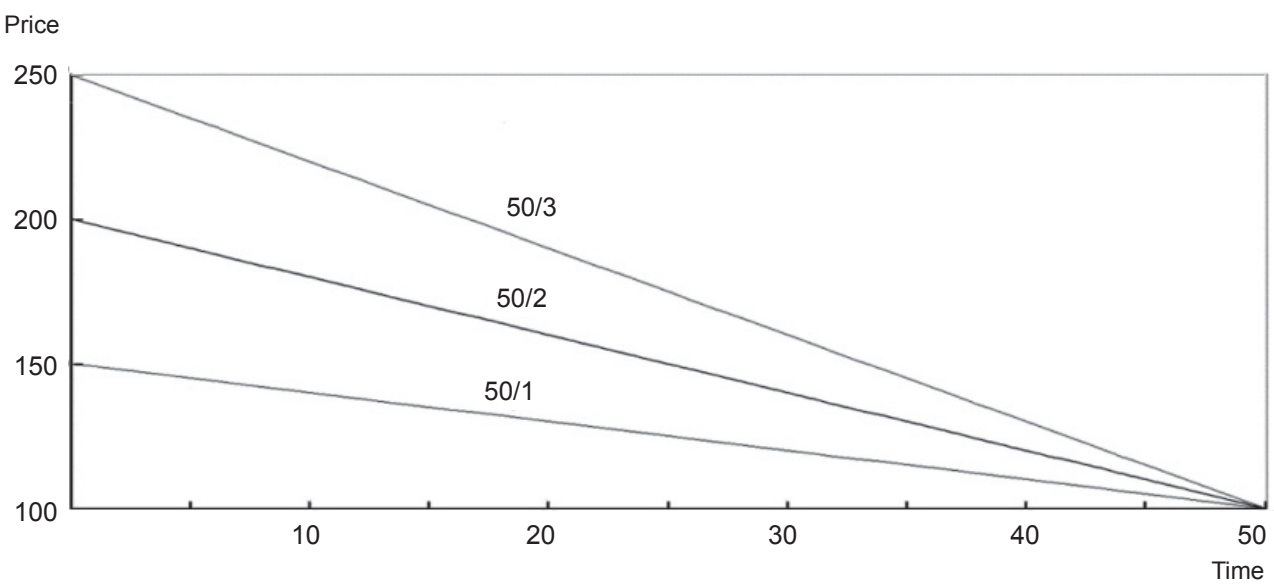

Note: constant yield to maturity $=0 \%, 3$ bonds with maturity 50 years and coupon rates 1, 2 and $3 \%$ p.a. Vertical axis represents prices in per cent of face value, horizontal axis shows years.

Source: own calculation.

Using the Equation (7) for special cases of very low interest rates, the Figure 11 can be constructed. In case of the yield to maturity being around $-100 \%$, the Price/Yield figure looks according to Figure 11 panel a) (only for odd years to maturity) or according panel b) (only for even number of years to maturity). However, it does not have to be such a surreal yield to maturity since similar behaviour is observed for any yield to maturity within the range $-100 \%-0 \%$. The natural question emerges, however, whether it is relevant to speak about reasonable financial valuation and applicability using standard (but purely) mathematical approach under these very specific circumstances.

If the yield to maturity is from the interval $(-100 \%, 0 \%)$, there is only one possible volatility regime - "negative interest rate" volatility regime - , which is schematically illustrated in the Figure 12. The example of volatility development is for a typical coupon bond maturing in 15 years with the coupon rate of $3 \%$ and the frequency of coupon payments is equal to one. The calculated yield to maturity in this case varies between $-2 \%$ and $2 \%$ p.a. (panel a) and between $-10 \%$ p.a. and $-5 \%$ p.a. in panel b). Since there is only one volatility regime in the area of negative interest rates, it limits the scope for discussion of switching 
points of regimes significantly and the entire situation is basically easier than in the case of higher interest rates. (Constant yield curves are of a convex shape.) Since this subsection has showed rather theoretical possibilities providing empirical evidence for all goes beyond the scope of this text. Moreover, because of particular combinations needed for some combinations, any evidence is scarce and/or non-existing.

\section{Figure 11 | Price/Yield Charts for Very Low Interest Rates}

a)

Price

Price
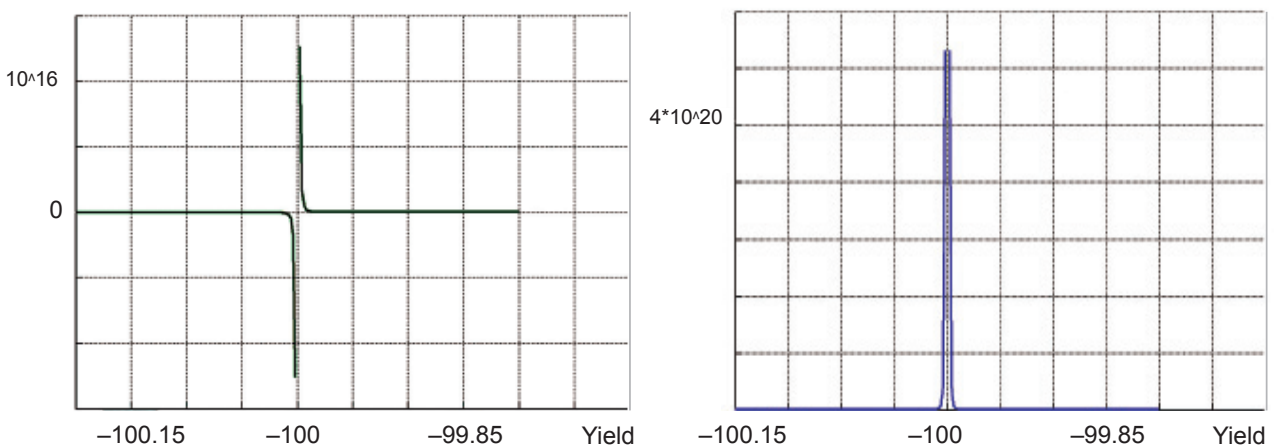

Note: odd years to maturity (3 years to maturity, coupon rate 1) (a), even years to maturity (4 years to maturity, coupon rate 1) (b). Vertical axis represents prices in per cent of face value, horizontal axis shows years.

Source: own calculation.

Figure 12 | Examples of Two Volatility Regimes

a)

Price

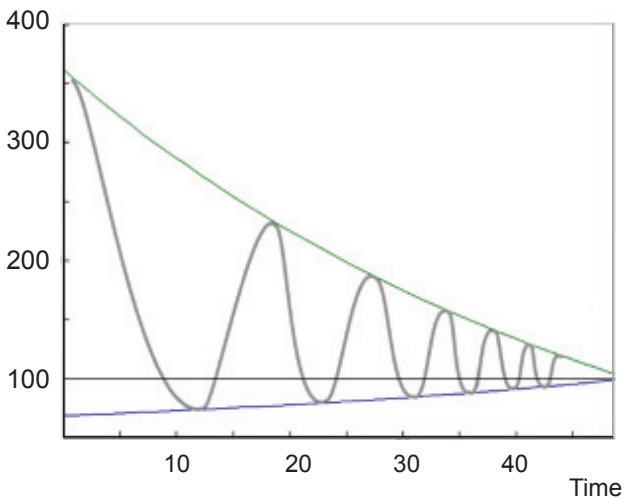

b)

Price

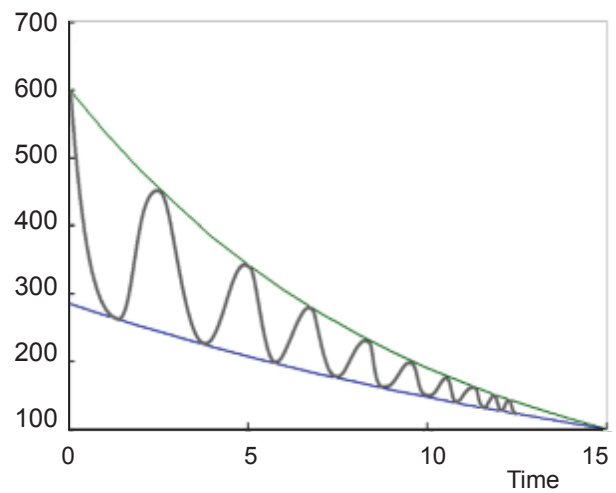

Note: a) half-negative-positive interest rate" volatility regime for the bond $(-2 \%, 2 \%, 50 / 1)$, b) full-negative interest rate" volatility regime for the bond $(-10 \%,-5 \%, 15 / 3)$. Vertical axis represents prices in per cent of face value, horizontal axis shows years.

Source: own calculation. 


\section{Volatility Regimes Switching for a Bond Portfolio}

Table 2a | Switching Points for Longer-Shorter Bond Portfolio

\begin{tabular}{|c|c|c|c|c|c|c|c|c|c|c|c|c|}
\hline \multirow{2}{*}{$\begin{array}{l}\text { matu- } \\
\text { rity }\end{array}$} & \multicolumn{4}{|c|}{ coupon $=0 / 0$} & \multicolumn{4}{|c|}{ coupon $=1 / 3$} & \multicolumn{4}{|c|}{ coupon $=5 / 5$} \\
\hline & 70 & 80 & 90 & 100 & 70 & 80 & 90 & 100 & 70 & 80 & 90 & 100 \\
\hline 1 & 0.06 & 0.06 & 0.05 & 0.05 & 0.21 & 0.21 & 0.21 & 0.21 & 0.28 & 0.28 & 0.28 & 0.28 \\
\hline 2 & 0.05 & 0.05 & 0.04 & 0.04 & 0.15 & 0.15 & 0.15 & 0.15 & 0.20 & 0.20 & 0.20 & 0.20 \\
\hline 3 & 0.05 & 0.04 & 0.04 & 0.04 & 0.13 & 0.13 & 0.13 & 0.13 & 0.17 & 0.17 & 0.17 & 0.17 \\
\hline 4 & 0.04 & 0.04 & 0.04 & 0.03 & 0.11 & 0.11 & 0.11 & 0.11 & 0.15 & 0.15 & 0.15 & 0.15 \\
\hline 5 & 0.04 & 0.04 & 0.04 & 0.03 & 0.10 & 0.10 & 0.10 & 0.10 & 0.14 & 0.13 & 0.13 & 0.13 \\
\hline 6 & 0.04 & 0.04 & 0.03 & 0.03 & 0.10 & 0.10 & 0.10 & 0.10 & 0.13 & 0.13 & 0.13 & 0.13 \\
\hline 7 & 0.04 & 0.03 & 0.03 & 0.03 & 0.09 & 0.09 & 0.09 & 0.09 & 0.12 & 0.12 & 0.12 & 0.12 \\
\hline 8 & 0.04 & 0.03 & 0.03 & 0.03 & 0.09 & 0.09 & 0.09 & 0.09 & 0.11 & 0.11 & 0.11 & 0.11 \\
\hline 9 & 0.03 & 0.03 & 0.03 & 0.03 & 0.09 & 0.09 & 0.08 & 0.08 & 0.11 & 0.11 & 0.11 & 0.11 \\
\hline 10 & 0.03 & 0.03 & 0.03 & 0.03 & 0.08 & 0.08 & 0.08 & 0.08 & 0.10 & 0.10 & 0.10 & 0.10 \\
\hline 15 & 0.03 & 0.03 & 0.02 & 0.02 & 0.08 & 0.08 & 0.08 & 0.08 & 0.09 & 0.09 & 0.09 & 0.09 \\
\hline 20 & 0.03 & 0.02 & 0.02 & 0.02 & 0.08 & 0.08 & 0.08 & 0.08 & 0.08 & 0.08 & 0.08 & 0.08 \\
\hline 25 & 0.02 & 0.02 & 0.02 & 0.02 & $\mathrm{n}$ & $\mathrm{n}$ & $\mathrm{n}$ & $\mathrm{n}$ & 0.08 & 0.08 & 0.08 & 0.08 \\
\hline 30 & 0.02 & 0.02 & 0.02 & 0.02 & $\mathrm{n}$ & $\mathrm{n}$ & $\mathrm{n}$ & $\mathrm{n}$ & 0.08 & 0.08 & 0.08 & 0.07 \\
\hline 35 & 0.02 & 0.02 & 0.02 & 0.02 & $\mathrm{n}$ & $\mathrm{n}$ & $\mathrm{n}$ & $\mathrm{n}$ & 0.07 & 0.07 & 0.07 & 0.07 \\
\hline 40 & 0.02 & 0.02 & 0.02 & 0.02 & $n$ & $n$ & $\mathrm{n}$ & $n$ & 0.07 & 0.07 & 0.07 & 0.07 \\
\hline 45 & 0.02 & 0.02 & 0.02 & 0.02 & $\mathrm{n}$ & $n$ & $\mathrm{n}$ & $\mathrm{n}$ & 0.07 & 0.07 & 0.07 & 0.07 \\
\hline 50 & 0.02 & 0.02 & 0.02 & 0.01 & $\mathrm{n}$ & $\mathrm{n}$ & $\mathrm{n}$ & $\mathrm{n}$ & 0.07 & 0.07 & 0.07 & 0.07 \\
\hline
\end{tabular}

Note: $\mathrm{n}$ - switching points not defined.

Source: own calculation.

Throughout the previous section the example of a typical bond and its life, through which its term to maturity decreases was utilized. The following scenarios illustrated in the Figures 4 to 7 can be also applied to a portfolio of bond, for example that consisting of four bonds with maturities 90, 15, 5 and 2 years (Figure 3). Based on the findings presented in the Section 3, our conclusion is that also in this case comparing mutual volatility depends significantly on the level of interest rates. For example, consider a case when a certain portfolio consists of long and short-term bonds. Then the switching point 1 (the volatility of a long-term bond starts to be lower than the volatility of a shorter one with respect to the interest rate level) is given in Table 2a. For illustration, shorter bonds with maturities from 1 to 50 years and fixed coupon rates $0 \%$ and $1 \%$ and $5 \%$ p.a. and long bonds with maturities $70-100$ years are considered. The coupon rate of the long-term bond is $0 \%, 3 \%, 5 \%$ p.a. Switching points for the portfolio of bond with maturity and perpetuity bond are shown in Table $2 \mathrm{~b}$. 
Yield to maturity is set to be changing from $0 \%$ to $100 \%$ p.a. All calculations are based on the Equation (12):

$$
-\frac{1 \cdot c_{1}}{(1+i)^{2}}-\frac{2 \cdot c_{1}}{(1+i)^{3}}-\ldots-\frac{m \cdot\left(c_{1}+100\right)}{(1+i)^{m+1}}=-\frac{1 \cdot c_{2}}{(1+i)^{2}}-\frac{2 \cdot c_{2}}{(1+i)^{3}}-\ldots-\frac{n \cdot\left(c_{2}+100\right)}{(1+i)^{n+1}}
$$

where $n$ is the term to maturity of the first bond and $m$ is the term to maturity of the second bond.

Table 2b | Switching Points for Portfolio of Bond with Maturity and Perpetuity Bond

\begin{tabular}{|l|c|c|c|c|}
\hline \multirow{2}{*}{ maturity } & coupon 1/1 & coupon 5/5 & coupon 9/9 & coupon 9/1 \\
\cline { 2 - 5 } & perp & perp & perp & perp \\
\hline $\mathbf{1}$ & 0.111 & 0.279 & 0.403 & 0.106 \\
\hline $\mathbf{2}$ & 0.079 & 0.200 & 0.290 & 0.074 \\
\hline $\mathbf{3}$ & 0.065 & 0.167 & 0.243 & 0.059 \\
\hline $\mathbf{4}$ & 0.057 & 0.147 & 0.216 & 0.051 \\
\hline $\mathbf{5}$ & 0.051 & 0.134 & 0.199 & 0.045 \\
\hline $\mathbf{6}$ & 0.047 & 0.125 & 0.186 & 0.041 \\
\hline $\mathbf{7}$ & 0.044 & 0.118 & 0.176 & 0.037 \\
\hline $\mathbf{8}$ & 0.041 & 0.112 & 0.168 & 0.034 \\
\hline $\mathbf{9}$ & 0.039 & 0.107 & 0.162 & 0.032 \\
\hline $\mathbf{1 0}$ & 0.038 & 0.103 & 0.157 & 0.030 \\
\hline $\mathbf{1 5}$ & 0.032 & 0.090 & 0.139 & 0.023 \\
\hline $\mathbf{2 0}$ & 0.028 & 0.083 & 0.129 & 0.019 \\
\hline $\mathbf{2 5}$ & 0.026 & 0.078 & 0.123 & 0.016 \\
\hline $\mathbf{3 0}$ & 0.024 & 0.074 & 0.118 & 0.014 \\
\hline $\mathbf{3 5}$ & 0.023 & 0.071 & 0.115 & 0.012 \\
\hline $\mathbf{4 0}$ & 0.022 & 0.069 & 0.112 & 0.011 \\
\hline $\mathbf{4 5}$ & 0.021 & 0.068 & 0.110 & 0.010 \\
\hline $\mathbf{5 0}$ & 0.020 & 0.066 & 0.108 & 0.009 \\
\hline $\mathbf{5 5}$ & 0.020 & 0.065 & 0.107 & 0.009 \\
\hline $\mathbf{6 0}$ & 0.019 & 0.064 & 0.106 & 0.008 \\
\hline $\mathbf{6 5}$ & 0.018 & 0.063 & 0.105 & 0.007 \\
\hline $\mathbf{7 0}$ & 0.018 & 0.062 & 0.104 & 0.007 \\
\hline $\mathbf{7 5}$ & 0.018 & 0.062 & 0.103 & 0.007 \\
\hline $\mathbf{8 0}$ & 0.017 & 0.061 & 0.102 & 0.006 \\
\hline $\mathbf{8 5}$ & 0.017 & 0.060 & 0.101 & 0.006 \\
\hline $\mathbf{9 0}$ & 0.017 & 0.060 & 0.101 & 0.006 \\
\hline $\mathbf{9 5}$ & 0.017 & 0.059 & 0.100 & 0.005 \\
\hline $\mathbf{1 0 0}$ & 0.016 & 0.059 & 0.100 & 0.005 \\
\hline
\end{tabular}

Source: own calculation. 
As previously, the value of the switching point 1 is found as the minimum realization of $i$ when solving the Equation (12). Conversely to the individual bond case, the switching point 2 now loses its financial sense for comparison of two different bonds (it is not defined; see the definition of switching point 2 in the Section 4).

\subsection{Economic impact of volatility regimes switching - a bird's-eye view}

Regimes switching points have an impact on volatility development style at the time of issuance and also on many practical activities associated with this issue. For example, higher price changes of ten-year futures price compared with five-year futures (Figure 1, see above) become conversely lower if the interest rates level increases over the switching point 1. We can also assume that for example the value of futures market minimum price ticks (closely connected to the measured volatility) can be switched between short and long-term maturities with respect to the level of interest rates in an economy. Similarly, margin levels can be switched in the same way. Typical investors' or risk managers' assumption in this case (the higher the maturities, the higher the risk) is not always correct.

It can be also claimed that for higher maturities the switching point 1 has a certain practical value as the values vary between $2 \%$ and $0.1 \%(50-1200$ years to maturity and zero coupons). On real financial market are only occasionally found traded instruments with such long maturities. There have been (traded) bond securities with the maturity of 1000 years (Canadian Pacific Railway, Ltd. 4\% and maturity in 2883) or 100 years (Disney or Coca-Cola). Individual panels of Figure 10 offer some further empirical evidence. Panel a) there is a price development of bond with maturity 3013 (DOENER 6.25 3013) with yield to maturity 4.6 and which volatility development should be in "non-typical" volatility regime. Supporting empirical volatility data are in the Figure 13 (panels b, c, d, and e). While such volatility developments support "non-typical" volatility regime (panels f, g) are US Treasury bonds in the "typical" regime with decreasing volatility.

Table 3 provides further evidence that not only US firms but also their European counterparts have issued bonds with very long maturities; for example the French electricity company (Électricité de France, EDF) with maturity after 2110. One explanation for such behaviour can be associated with industry-specific (investment) costs-income cash flow profiles that issuing firms need to match (long-term projects such as power stations whose investment and production cycles or cost-revenue profiles are rather specific, foreign direct investments, etc.). ${ }^{10}$ Another explanation for such behaviour is the existence of zero-lower bound that enables firms to refinance their liabilities under more favourable conditions and fix them for a relatively long period of time. ${ }^{11}$ In total, there are as many as 71 issues with their maturity after 2100 according to data provided by Reuters.

10 The particulars of FDI type of investments are explained for example in Žd'árek (2009).

11 Given the recent changes in monetary policy measures of the ECB and the announcement of quantitative easing $(\mathrm{QE})$, such behaviour could become more "standard" than it used to be in the past (reducing and fixing low borrowing costs, mainly as the expected end of the QE measures will approach). 
Figure 13 | Price Development of a Bond with Maturity 3013 (DOENER 6.25 3013)

a) Very long maturity

Price

Daily DK094337054 =

3.7. $2013-14.10 .2015$

EUR

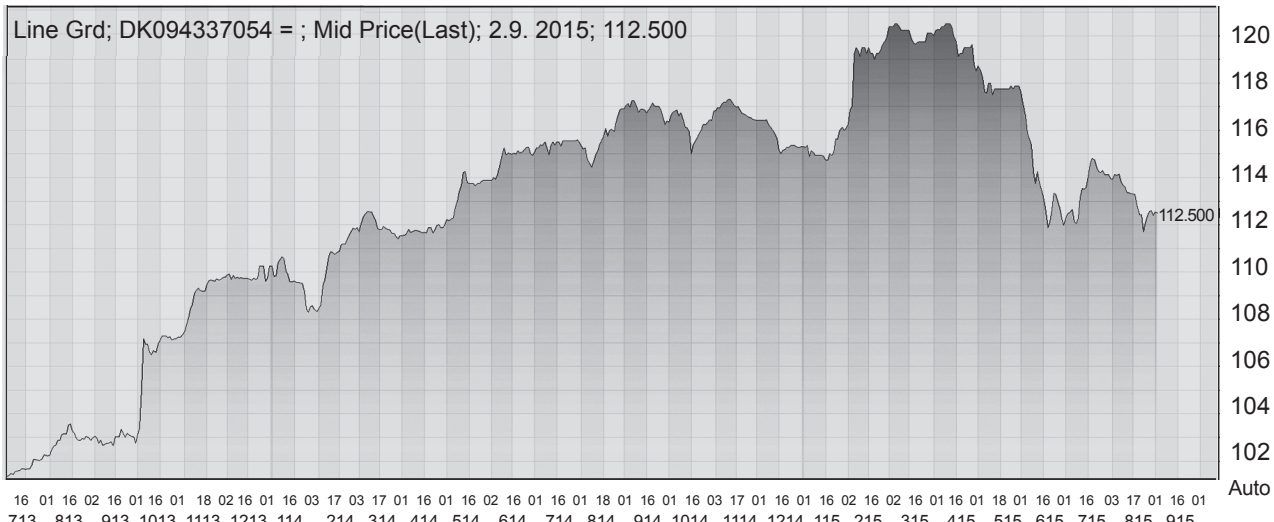

b)

Volatility

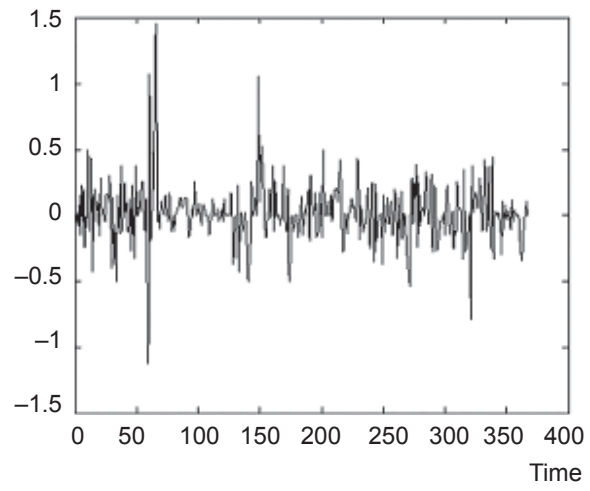

d)

Price

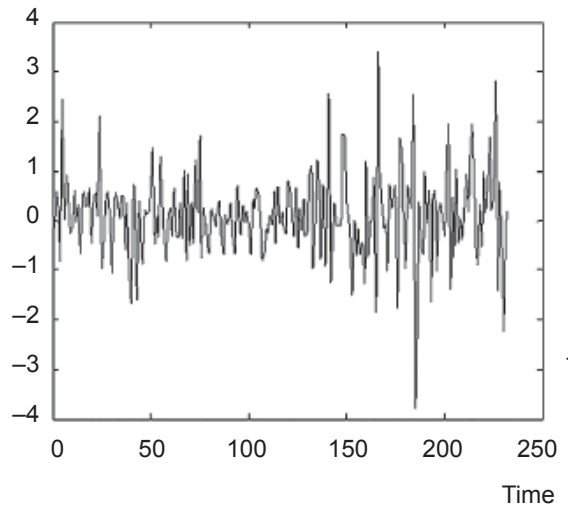

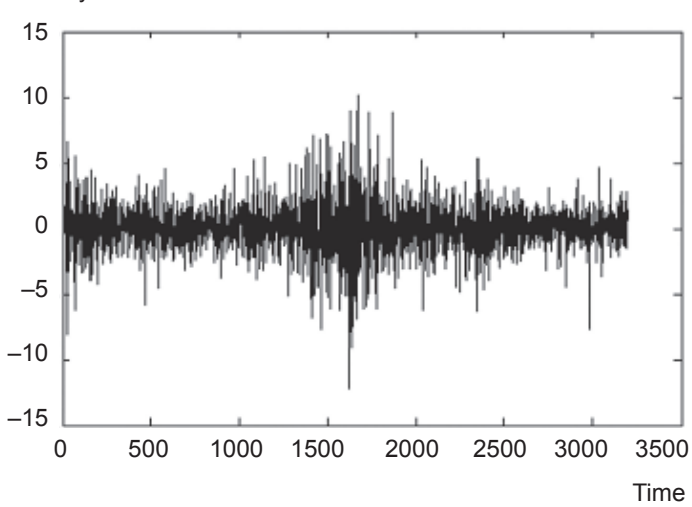

e)

Price

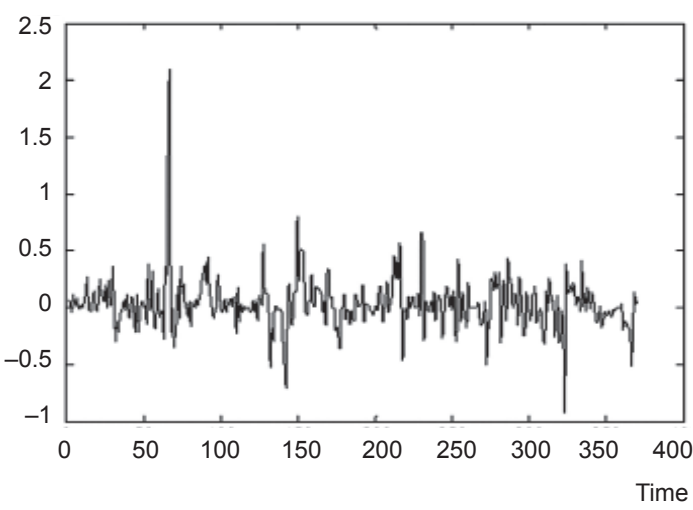



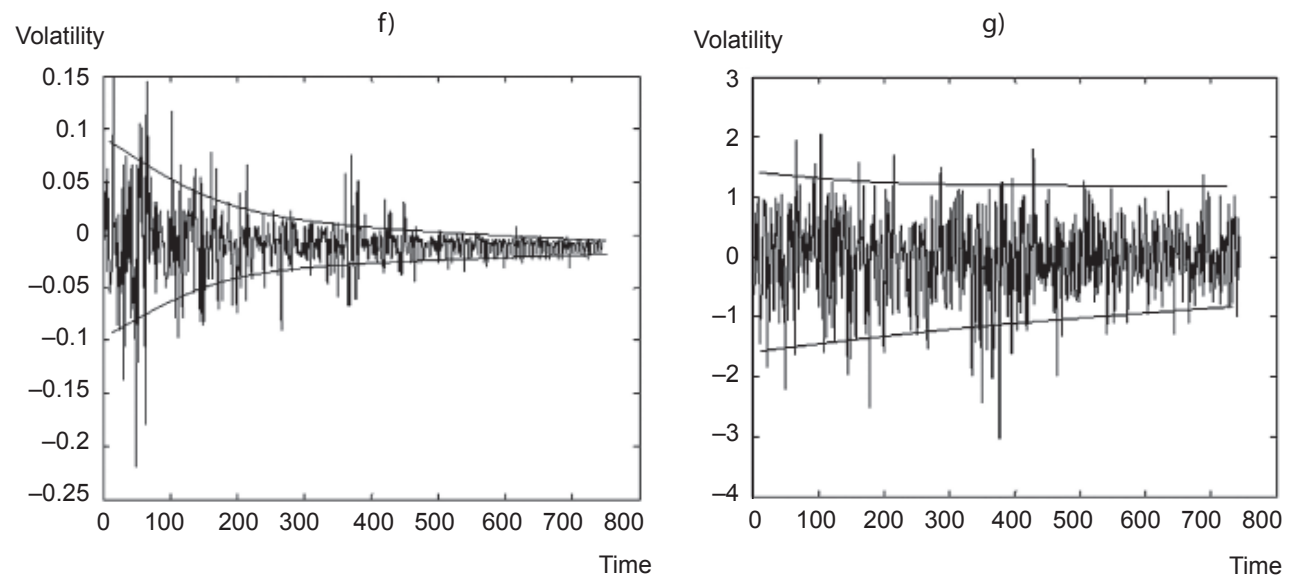

Note: (Doener 6.25 3013) in "non-typical" volatility regime (a), DOENR 4.875 08-JUL-3013 - daily volatility series (b), Canadian Pacific Railway LTD 2882 - daily volatility series (c), EDF 6.000 23-JAN-2114 - daily volatility series (d), DOENR 6.250 26-JUN-3013 - daily volatility series (e),UST 2.625 31-DEC-2014 - daily volatility series (f), UST 6.500 15-NOV-2026 - daily volatility series (g).

Source: Reuters, own adaptation.

Table 3 | Bonds with Maturity Date beyond 2110 (Reuters, as of 2/9/2015)

\begin{tabular}{|c|c|c|c|c|c|c|}
\hline Issuer Name & Coupon & Maturity & ISIN & $\begin{array}{l}\text { Principal } \\
\text { Currency }\end{array}$ & Coupon Type & $\begin{array}{l}\text { Yield to } \\
\text { Maturity }\end{array}$ \\
\hline Dong Energy A/S & 3 & 06-Nov-3015 & XS1227607402 & Euro & $\begin{array}{l}\text { Fixed } \\
\text { Resettable }\end{array}$ & 3.7223030 \\
\hline TDC A/S & 3.5 & 26-Feb-3015 & XS1195581159 & Euro & $\begin{array}{l}\text { Fixed } \\
\text { Resettable }\end{array}$ & 4.1340200 \\
\hline Dong Energy A/S & 4.875 & 08-Jul-3013 & XS0943371194 & Euro & $\begin{array}{l}\text { Fixed } \\
\text { Resettable }\end{array}$ & 4.4432110 \\
\hline Dong Energy A/S & 6.25 & 26-Jun-3013 & XS0943370543 & Euro & $\begin{array}{l}\text { Fixed } \\
\text { Resettable }\end{array}$ & 5.0886250 \\
\hline $\begin{array}{l}\text { Canadian Pacific } \\
\text { Railway Ltd }\end{array}$ & 4 & $25-J u l-2882$ & NL0000272813 & $\begin{array}{l}\text { British } \\
\text { Pound }\end{array}$ & $\begin{array}{l}\text { Plain Vanilla } \\
\text { Fixed }\end{array}$ & -- \\
\hline $\begin{array}{l}\text { BNP Paribas Arbi- } \\
\text { trage Issuance }\end{array}$ & 7.25 & 30-Jun-2218 & XS1186889454 & US Dollar & $\begin{array}{l}\text { Plain Vanilla } \\
\text { Fixed }\end{array}$ & -- \\
\hline Astana-Finans AO & 0 & 31-Dec-2200 & XS1056725358 & $\begin{array}{l}\text { Kazakhstani } \\
\text { Tenge }\end{array}$ & Zero Coupon & -- \\
\hline Frontera Capital BV & 0 & 31-Dec-2200 & XS1116570760 & US Dollar & Zero Coupon & -- \\
\hline MSD SARL & 3.3 & 31-Dec-2200 & XS1091754470 & Euro & $\begin{array}{l}\text { Plain Vanilla } \\
\text { Fixed }\end{array}$ & -- \\
\hline SG Issuer SA & 0 & 31-Dec-2200 & XS1101730916 & US Dollar & Zero Coupon & -- \\
\hline MSD SARL & 3.3 & 31-Dec-2200 & XS1091754041 & Euro & $\begin{array}{l}\text { Plain Vanilla } \\
\text { Fixed }\end{array}$ & -- \\
\hline
\end{tabular}


Table 3 | Continuation

\begin{tabular}{|c|c|c|c|c|c|c|}
\hline $\begin{array}{l}\text { Lana Trade Receiv- } \\
\text { ables SARL }\end{array}$ & 15 & 31-Dec-2200 & XS1239127993 & Euro & $\begin{array}{l}\text { Plain Vanilla } \\
\text { Fixed }\end{array}$ & - \\
\hline $\begin{array}{l}\text { BOCI Financial } \\
\text { Products Ltd }\end{array}$ & 0 & $20-F e b-2200$ & XS1157213726 & $\begin{array}{l}\text { Hong Kong } \\
\text { Dollar }\end{array}$ & $\begin{array}{l}\text { Zero } \\
\text { Coupon }\end{array}$ & - \\
\hline $\begin{array}{l}\text { BOCI Financial } \\
\text { Products Ltd }\end{array}$ & 0 & $20-F e b-2200$ & XS1156537257 & $\begin{array}{l}\text { Hong Kong } \\
\text { Dollar }\end{array}$ & $\begin{array}{l}\text { Zero } \\
\text { Coupon }\end{array}$ & - \\
\hline $\begin{array}{l}\text { Flag Income Notes } \\
\text { Pty Ltd }\end{array}$ & 0.1 & 31-Dec-2199 & AU3CB0203677 & $\begin{array}{l}\text { Australian } \\
\text { Dollar }\end{array}$ & $\begin{array}{l}\text { Plain Vanilla } \\
\text { Fixed }\end{array}$ & - \\
\hline $\begin{array}{l}\text { Assicurazioni } \\
\text { Generali SpA }\end{array}$ & 7.678 & 31-Dec-2131 & XS0399861326 & Euro & $\begin{array}{l}\text { Fixed then } \\
\text { Floating }\end{array}$ & 4.3668880 \\
\hline $\begin{array}{l}\text { Belgium, Kingdom } \\
\text { of (Govern) }\end{array}$ & 2.5 & 09-Sep-2115 & BE6280748953 & Euro & $\begin{array}{l}\text { Plain Vanilla } \\
\text { Fixed }\end{array}$ & - \\
\hline SNCF Reseau & 2.777 & 29-Jul-2115 & XS1265369840 & Euro & $\begin{array}{l}\text { Plain Vanilla } \\
\text { Fixed }\end{array}$ & - \\
\hline $\begin{array}{l}\text { Petrobras Global } \\
\text { Finance BV }\end{array}$ & 6.85 & 05-Jun-2115 & US71647NAN93 & US Dollar & $\begin{array}{l}\text { Plain Vanilla } \\
\text { Fixed }\end{array}$ & 9.1630390 \\
\hline $\begin{array}{l}\text { Mexico, Republic } \\
\text { of (Govern) }\end{array}$ & 4 & 15-Mar-2115 & XS1218289103 & Euro & $\begin{array}{l}\text { Plain Vanilla } \\
\text { Fixed }\end{array}$ & 4.7066900 \\
\hline $\begin{array}{l}\text { Massachusetts } \\
\text { Institute of Tech }\end{array}$ & 4.678 & 01-Jul-2114 & US575718AB76 & US Dollar & $\begin{array}{l}\text { Plain Vanilla } \\
\text { Fixed }\end{array}$ & 4.4912190 \\
\hline $\begin{array}{l}\text { Mexico, Republic } \\
\text { of (Govern) }\end{array}$ & 5.625 & 19-Mar-2114 & XS1046593908 & $\begin{array}{l}\text { British } \\
\text { Pound }\end{array}$ & $\begin{array}{l}\text { Plain Vanilla } \\
\text { Fixed }\end{array}$ & 5.7745400 \\
\hline $\begin{array}{l}\text { Electricite de } \\
\text { France SA }\end{array}$ & 6 & 23-Jan-2114 & FR0011710284 & $\begin{array}{l}\text { British } \\
\text { Pound }\end{array}$ & $\begin{array}{l}\text { Plain Vanilla } \\
\text { Fixed }\end{array}$ & 4.8050370 \\
\hline $\begin{array}{l}\text { Electricite de } \\
\text { France SA }\end{array}$ & 6 & 22-Jan-2114 & USF2893TAL01 & US Dollar & $\begin{array}{l}\text { Plain Vanilla } \\
\text { Fixed }\end{array}$ & 5.4380000 \\
\hline $\begin{array}{l}\text { Electricite de } \\
\text { France SA }\end{array}$ & 6 & 22-Jan-2114 & US268317AL89 & US Dollar & $\begin{array}{l}\text { Plain Vanilla } \\
\text { Fixed }\end{array}$ & 5.4216450 \\
\hline $\begin{array}{l}\text { Cleveland Clinic } \\
\text { Foundation }\end{array}$ & 4.858 & 01-Jan-2114 & US18600TAA07 & US Dollar & $\begin{array}{l}\text { Plain Vanilla } \\
\text { Fixed }\end{array}$ & 5.0512220 \\
\hline Hamilton College & 4.75 & 01-Jul-2113 & US40728TAA16 & US Dollar & $\begin{array}{l}\text { Plain Vanilla } \\
\text { Fixed }\end{array}$ & 5.3312220 \\
\hline $\begin{array}{l}\text { Grupo Industrial } \\
\text { Canal SA }\end{array}$ & 8 & 30-Dec-2112 & PAL1201121B0 & US Dollar & $\begin{array}{l}\text { Plain Vanilla } \\
\text { Fixed }\end{array}$ & - \\
\hline $\begin{array}{l}\text { Trustees } \\
\text { of the Unive } \\
\text { of Pennsyl }\end{array}$ & 4.674 & 01-Sep-2112 & US91481CAA80 & US Dollar & $\begin{array}{l}\text { Plain Vanilla } \\
\text { Fixed }\end{array}$ & 4.8112210 \\
\hline $\begin{array}{l}\text { Enbridge Pipelines } \\
\text { Inc }\end{array}$ & 4.1 & 18-Jul-2112 & CA29250ZAP32 & $\begin{array}{l}\text { Canadian } \\
\text { Dollar }\end{array}$ & $\begin{array}{l}\text { Plain Vanilla } \\
\text { Fixed }\end{array}$ & 4.1860000 \\
\hline Bowdoin College & 4.693 & 01-Jul-2112 & US102291AA91 & US Dollar & $\begin{array}{l}\text { Plain Vanilla } \\
\text { Fixed }\end{array}$ & 5.0512220 \\
\hline Tufts University & 5.017 & 15-Apr-2112 & US899043AA10 & US Dollar & $\begin{array}{l}\text { Plain Vanilla } \\
\text { Fixed }\end{array}$ & 4.8412200 \\
\hline
\end{tabular}

Source: Reuters (2015), own adaptation. 
Similarly, the case of lower maturities and higher yields are also plausible. Table 4 lists some examples of high yield bonds. According to the Reuters' database, there were 371 bonds (in September 2015) with a yield to maturity between 20-60\% p.a. ${ }^{12}$ (According to Reuters' database statistics, there are 1667 issues with a yield to maturity between $20-100 \%$ p.a. and 777 issues of yield higher than $100 \%$, as of early September 2015).

Table 4 | Bonds with Yield to Maturity of about 29\% p.a. (Reuters, as of 2/9/2015)

\begin{tabular}{|c|c|c|c|c|c|c|}
\hline Issuer Name & Coupon & Maturity & ISIN & $\begin{array}{l}\text { Principal } \\
\text { Currency }\end{array}$ & Coupon Type & $\begin{array}{c}\text { Yield } \\
\text { to Maturity }\end{array}$ \\
\hline $\begin{array}{l}\text { Linn Energy } \\
\text { LLC }\end{array}$ & 6.5 & 15-Sep-2021 & US536022AL02 & US Dollar & $\begin{array}{l}\text { Plain Vanilla } \\
\text { Fixed Coupon }\end{array}$ & 29.3945410 \\
\hline $\begin{array}{l}\text { Abengoa } \\
\text { Finance SAU }\end{array}$ & 8.75 & 01-Nov-2017 & US00289RAA05 & US Dollar & $\begin{array}{l}\text { Plain Vanilla } \\
\text { Fixed Coupon }\end{array}$ & 29.3927780 \\
\hline $\begin{array}{l}\text { Abengoa } \\
\text { Finance SAU }\end{array}$ & 8.75 & 01-Nov-2017 & USE0002VAC84 & US Dollar & $\begin{array}{l}\text { Plain Vanilla } \\
\text { Fixed Coupon }\end{array}$ & 29.3927780 \\
\hline $\begin{array}{l}\text { Fedl Home } \\
\text { Loan Mrtg }\end{array}$ & 5.66 & & US3134006655 & US Dollar & $\begin{array}{l}\text { Plain Vanilla } \\
\text { Fixed Coupon }\end{array}$ & 29.3684560 \\
\hline $\begin{array}{l}\text { NBG Finance } \\
\text { PLC }\end{array}$ & 4.375 & 30-Apr-2019 & XS1063244682 & Euro & $\begin{array}{l}\text { Plain Vanilla } \\
\text { Fixed Coupon }\end{array}$ & 29.3452970 \\
\hline $\begin{array}{l}\text { African Bank } \\
\text { Ltd }\end{array}$ & 8.125 & 24-Feb-2017 & XS0751016865 & US Dollar & $\begin{array}{l}\text { Plain Vanilla } \\
\text { Fixed Coupon }\end{array}$ & 29.3014470 \\
\hline $\begin{array}{l}\text { TransFin-M } \\
\text { PAO }\end{array}$ & 10.5 & 17-Sep-2019 & RU000A0JUUG8 & Russian Rub & $\begin{array}{l}\text { Plain Vanilla } \\
\text { Fixed Coupon }\end{array}$ & 29.3000000 \\
\hline $\begin{array}{l}\text { Avangard - } \\
\text { Agro OAO }\end{array}$ & 12 & 10-Oct-2017 & RU000A0JUW56 & Russian Rub & $\begin{array}{l}\text { Step Up / Step } \\
\text { Down }\end{array}$ & 29.2900000 \\
\hline $\begin{array}{l}\text { Prospect } \\
\text { Holding }\end{array}$ & 10.25 & 01-Oct-2018 & US74349CAA62 & US Dollar & $\begin{array}{l}\text { Plain Vanilla } \\
\text { Fixed Coupon }\end{array}$ & 29.2887990 \\
\hline Abengoa & 6.25 & 17-Jan-2019 & XS0875275819 & Euro & $\begin{array}{l}\text { Plain Vanilla } \\
\text { Fixed Coupon }\end{array}$ & 29.2882350 \\
\hline $\begin{array}{l}\text { Domashniye } \\
\text { den'gi }\end{array}$ & 27 & 27-Apr-2017 & RU000A0JS7J4 & Russian Rub & $\begin{array}{l}\text { Step Up / Step } \\
\text { Down }\end{array}$ & 29.2300000 \\
\hline $\begin{array}{l}\text { NCSG Leas- } \\
\text { ing Ltd }\end{array}$ & 9.5 & 15-Aug-2019 & USC6100PAA50 & US Dollar & $\begin{array}{l}\text { Plain Vanilla } \\
\text { Fixed Coupon }\end{array}$ & 29.2071410 \\
\hline
\end{tabular}

Source: Reuters (2015), own adaptation.

Other financial market activities which are closely connected to sensitivity and volatility as for example hedging or speculations priorities should be significantly influenced by the reaching of switching point 1 or even by switching point 2 .

12 For comparison, there were only 324 bonds in April 2014. 


\section{Conclusions}

This text introduced a definition of three different regimes of common bond clean price volatility and examines theoretical and practical repercussions of such phenomena as an extension to the existing literature. A way of determining values of switching points between these regimes with respect to the level of interest rates using numerical calculations are presented and explained. Consequently, we proceeded with investigation regarding parameters' values and their effects, coupled with a discussion of economic implications of this property of bonds. It was also shown that such behaviour of individual instruments can be generalised for bonds portfolios. Several examples are provided throughout the text that illustrates mathematical (purely theoretical) concepts based and their empirical counterparts.

Our illustrations included numerically solving for switching points for maturities from 1 up to 1200 years that show that the switching point 1 (between regime of the "typical" development and other regimes) is of lower value for higher maturities, which is also in accordance with Fuller, Settle (1984). We can also state that for higher maturities the "switching" point has its practical value within the meaning of today's very low levels or even negative interest rates. The switching point 2 (starting point of "inverse" volatility development) is not of value less than $50 \%$. This value is given by switching point 1 between the lowest maturities for each coupon. If the clean price of a bond is developing inside the volatility envelopes, its sensitivity (volatility) increases/decreases according to the shown shape of the envelope.

Section 3 showed that the comparison of mutual volatility of bonds inside a certain portfolio also depends on the level of interest rates. When a portfolio of long (and also perpetuity) and shorter-term bonds is utilized, then the switching point 1 is similar to individual bond cases. Similarly, values of switching points increase with the higher coupon rate. Even though this is one of the first studies on the topic of the bond price volatility, our text clearly shows its importance and relevance both from the theoretical and empirical point of view, for example for portfolio managers.

As a consequence of recent changes in economic environment such as renowned problems of some Mediterranean countries and ECB's policy measures, effects under specific circumstances are also presented (negative interest rates). Volatility behaviour of bond instruments in case of negative interest rates was examined. We found that in this case the situation of volatility regimes is not as complex as in the above-lower-zero-boundlying interest rates. There is only one regime and no switching point. There are some possible topics and extensions left for further research such as effects of standard and nonstandard monetary policy measures on interest rate sensitive instruments, loan portfolios of commercial banks and so on and forth. 


\section{Appendix}

Matlab code for the reproduction of the results of 1 bond life in the Tables $1 \mathrm{a}, \mathbf{1 b}$ :

Mat lab code for the reproduction of the results of 1 bond life:

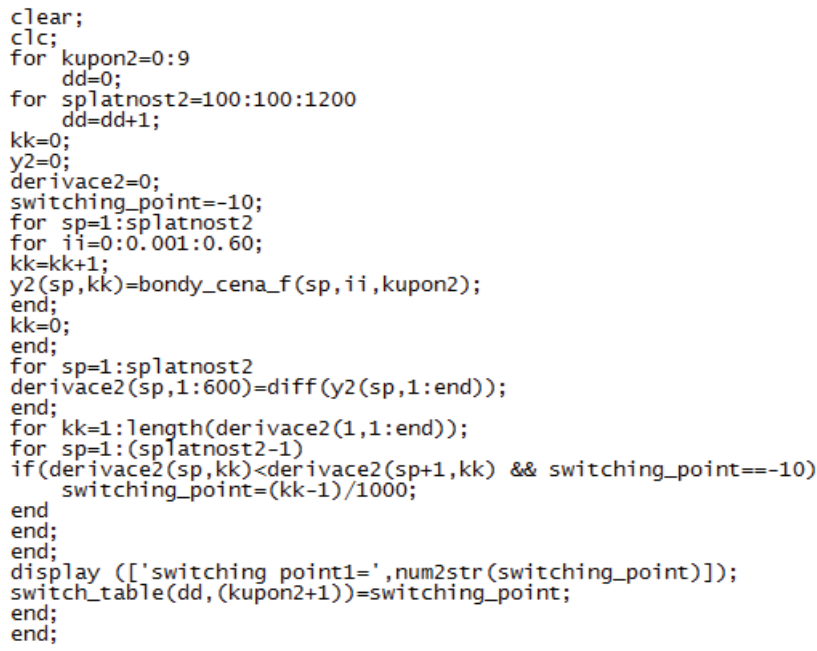

Matlab code for the reproduction of the results of bond portfolio in the Tables $2 \mathrm{a}, \mathbf{2 b}$

Matlab code for the reproduction of the results of bond portfolio:

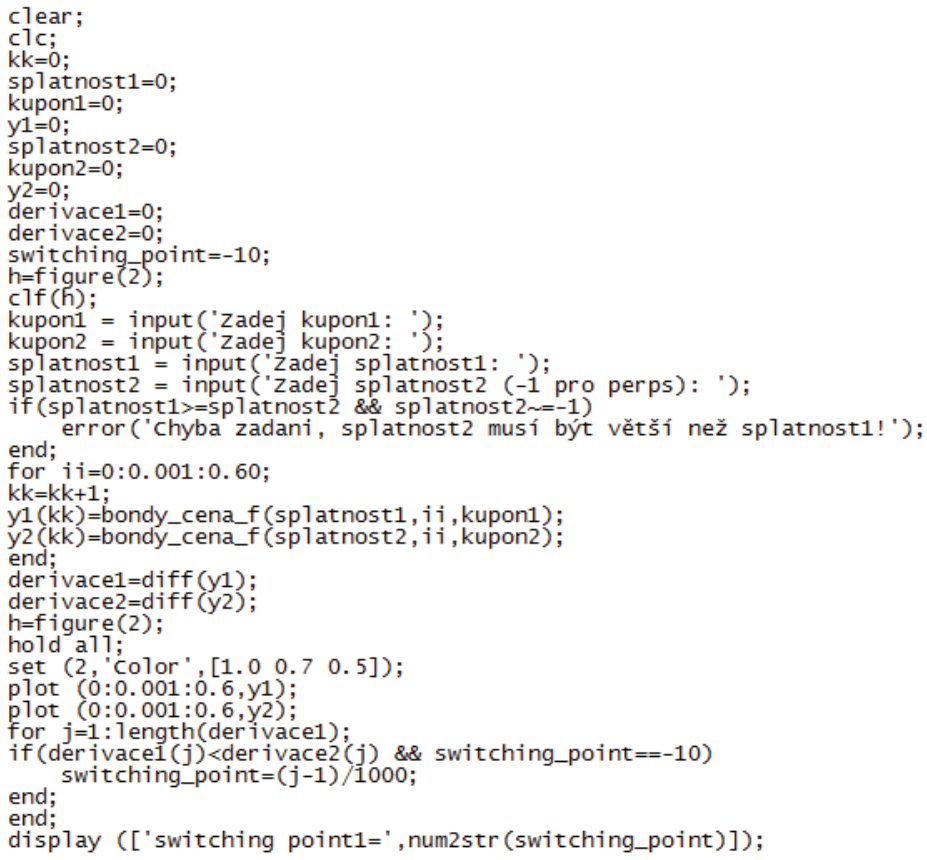




\section{References}

Bartle, R. G., Sherbert, D. R. (2011). Introduction to Real Analysis (4th Edition). John Wiley \& Sons, Hoboken, NJ. ISBN 978-0-471-43331-6.

Blahová, N. (2015). Analysis of the Relation between Macroprudential and Microprudential Policy. European Financial and Accounting Journal, 10(1), 33-47, https://doi. org/10.18267/j.efaj.136

Brůna, K., Blahová, N. (2016). Systemic Liquidity Shocks and Banking Sector Liquidity Characteristics on the Eve of Liquidity Coverage Ratio Application - The Case of the Czech Republic. Journal of Central Banking Theory and Practice [online], 5(1), 159-184, https:// doi.org/10.1515/jcbtp-2016-0008

Chance, D. M., Jordan, J. V. (1966). Duration, Convexity, and Time as Components of Bond Returns. The Journal of Fixed Income, 6(2), 88-96, https://doi.org/10.3905/jfi.1996.408173

Dzikevičius, A., Vetrov, V. (2013). Investment Portfolio Management Using the Business Cycle Approach. Business: Theory and Practice/Verslas: Teorija ir Praktika, 14(1), 57-63, https:// doi.org/10.3846/btp.2013.07

Fabozzi, F., J. (1993). Fixed Income Mathematics, Chicago: Probus, Publishing Company.

Fabozzi F., J. (2010). Bond Markets, Analysis and Strategies (seventh edition). Prentice Hall.

Fabozzi, F. J., Fabozzi, T., D. (1995): The Handbook of Fixed Income Securities (Fourth Edition). Irwin, Professional Publishing.

Fuller, R. J., Settle, J. W. (1984). Determinants of Duration and Bond Volatility. Journal of Portfolio Management, 10(4), 66-72, https://doi.org/10.3905/jpm.1984.408974

Giacometti, R., Ortobelli, S., Tichý, T. (2015). Portfolio Selection with Uncertainty Measures Consistent with Additive Shifts. Prague Economic Papers, 24(1), 3-16, https://doi. org/10.18267/j.pep.497

Horváth, R., Teplý, P. (2013). Risk Management of Building Societies in the Czech Republic. Ekonomický časopis/Journal of Economics, 61(1), 24-46.

Janda, K., Svárovská, B. (2010). Investing into Microfinance. Journal of Business Economics and Management, 11(3), 483-510, https://doi.org/10.3846/jbem.2010.24

Janda, K., Rausser, G., Svárovská, B. (2014). Can Investment in Microfinance Funds Improve Risk-Return Characteristics of a Portfolio? Technological and Economic Development of Economy, 20(4), 673-695, https://doi.org/10.3846/20294913.2014.869514

Kang, J. C., Chen, A. H. (2002). Evidence on Theta and Convexity in Treasury Returns. The Journal of Fixed Income, 12(1), 41-50, https://doi.org/10.3905/jfi.2002.319317

Křepelova, M., Jablonský, J. (2013). Analýza státních dluhopisů jako indikátoru pro akciový trh (Analysis of Government Bonds as an Indicator for Stock Market), Politická ekonomie, 61(5), 605-622, https://doi.org/10.18267/j.polek.919

Lim, D., Li, L., Linetsky, V. (2012). Evaluating Callable and Putable Bonds: An Eigenfunction Expansion Approach. Journal of Economic Dynamics \& Control, 36(12), 1888-1908, https://doi.org/10.1016/j.jedc.2012.06.002

Litterman, R., Scheinkman, J., Weiss, L. (1991). Volatility and the Yield Curve. The Journal of Fixed Income, 1(1), 49-53, https://doi.org/10.3905/jfi.1991.692346

Litterman, R., Scheinkman, J. (1991). Common Factors Affecting Bond Returns. The Journal of Fixed Income, 1(1), 54-61, https://doi.org/10.3905/jfi.1991.692347 
Málek, J., Radová, J., Štěrba, F. (2007). Konstrukce výnosové křivky pomocí vládních dluhopisů v České republice (Yield Curve Construction Using Government Bonds in the Czech Republic). Politická ekonomie, 55(6), 792-808, https://doi.org/10.18267/j.polek.624

Meng, L. A., Gwilym, O. A. B., Varas, J., C. (2009). Volatility Transmission Among the CDS, Equity, and Bond Markets. Journal of Fixed Income, 18(3), 33-46, https://doi.org/10.3905/ jfi.2009.18.3.033

Musílek, P. (2011). Trhy cenných papírů (2. vydáni). Praha: Ekopress (in Czech), ISBN 978-80-86929-70-5.

Ortobelli, S., Tichý, T. (2015). On the Impact of Semidenite Positive Correlation Measures in Portfolio Theory. Annals of Operations Research, 235(1), 625-652, https://doi. org/10.1007/s10479-015-1962-x.

Rutkauskas, A. V., Stasytytè, V., Maknickienèa, N. (2014). Government Debt as the Integral Portfolio of Assets and Liabilities Generated by Debt. Journal of Business Economics and Management, 15(1), 22-40, https://doi.org/10.3846/16111699.2013.815129

Smit, L. A., Swart, B. B. (2006). Calculating the Price of Bond Convexity. Journal of Portfolio Management, 32(2), 99-106, https://doi.org/10.3905/jpm.2006.611809

Stádník, B. (2012). Teorie a praxe dluhopisů I, (Theory and Praxis of Bonds I.) Prague: Oeconomica. ISBN 9788024519197.

Stádník, B. (2014). The Volatility Puzzle of Bonds. $8^{\text {th }}$ International Scientific Conference: Business and Management 2014, May 15-16, 2014, Vilnius.

Steeley, J. M. (2006). Volatility Transmission between Stock and Bond Markets. Journal of International Financial Markets, Institutions and Money, 16(1), 71-86, https://doi. org/10.1016/j.intfin.2005.01.001

Tvaronavičienea, M., Michailova, J. (2006). Factors Affecting Securities Prices: Theoretical versus Practical Approach. Journal of Business Economics and Management, 7(4), 213-222.

Visokavičienè, B. (2008). Money Supply and Assets Value. Business: Theory and Practice/Verslas: Teorija ir Praktika, 9(3), 210-214, https://doi.org/10.3846/1648-0627.2008.9.210-214

Webb, M. S. (2015). Negative Yields Are All around US. The Financial Times, FT Money, Saturday 31 January 2015, 8.

Wilmott, P. (2006). Paul Wilmott on Quantitative Finance ( $2^{\text {nd }}$ Ed.). John Wiley \& Sons Ltd., UK, Chichester 2006.

Ždárek, V. (2009). Moderní způsoby produkce a přímé zahraniční investice (Modern Methods of Production and Foreign Direct Investment), Politická ekonomie, 57(4), 509-543, https:// doi.org/10.18267/j.polek.696

\section{Data sources:}

Eurex Exchange Database (online). Eurex, Eschborn, 2015.

Reuters Eikon Database (online). Reuters, London, 2015. 